\title{
The Bathypelagic Mysid Gnathophausia (Crustacea) and Its Distribution in the Eastern Pacific Ocean
}

\author{
Linda HaithCock PequegnaT ${ }^{1}$
}

A NEED HAS LONG EXISTED for an improved collecting device for capturing the larger and more actively swimming bathypelagic animals of the sea. The Isaacs-Kidd Midwater Trawl was developed at the University of California's Scripps Institution of Oceanography in 1950 and has largely satisfied this need (SIO Reference 53-3, 1953).

Bathypelagic specimens have frequently been captured in the deeper hauls of the standard one-meter plankton nets. However, the selfdepressing midwater trawl, larger and capable of greater depths (up to $4000 \mathrm{~m}$ ) and speeds (up to 5 knots) than the standard 1-meter net, has given us more productive samplings of the larger bathypelagic forms (Figs. 1 and 2 ). In addition, the midwater trawl has captured many species of deep-sea fishes not previously reported in the Pacific as well as species entirely new to scientific literature-forms which apparently have previously eluded capture at these depths by traditional, less effective collecting devices.

The midwater trawl collections made by the Scripps Institution of Oceanography in the eastern Pacific Ocean during the period 195053 were examined for the presence of the mysidacean genus Gnatbophausia, a striking crimson red crustacean conspicuous in midwater trawl hauls from bathypelagic waters. The order Mysidacea has been divided into two subgroups based upon very widely separating morphological characteristics: the suborder Mysida and the phylogenetically more primitive suborder Lophogastrida. Gnathophausia is the "giant" genus in the suborder Lophogastrida, containing the largest mysids ever reported. All of the species of Gnathophausia are bathypelagic and

\footnotetext{
${ }^{1}$ Formerly with the Scripps Institution of Oceanography, University of California at La Jolla, California. Present address: c/o Department of Oceanography, Texas A \& $M$ University, College Station, Texas. Manuscript received March 23, 1964.
}

are practically never encountered in shallow water.

Specimens of Gnathophausia have been described from as early as the Challenger Expedition in 1873-76 (Sars, 1885 and WillemoesSuhm, 1875), and have been reported from all parts of the world from such other pre-twentieth century expeditions as the Talisman, the Albatross, the Oceania, and the Investigator. The Dana Expedition in 1928-30 and the Discovery Expeditions in the 1920's and 1930's have revealed specimens of this genus in greater numbers and from even more widespread locations throughout the world. Prior to the Dana Expedition relatively few specimens of Gnathophausia had ever been captured-probably fewer than 100 altogether. A total of 1,051 specimens of Gnathophausia were taken by the Dana, adding considerably to our knowledge of this group of animals. The distribution and biology of Gnathophausia is reported in the greatest detail to date by Fage (1941) in his study of the vast Dana collections.

Few studies were made of bathypelagic animals in the eastern Pacific Ocean prior to the development of the midwater trawl and the subsequent collections made by the Scripps Institution during and after its development. Banner (1947) reported on one species of Gnatbophausia (involving 24 specimens) from the northeastern Pacific off Canada and Alaska, and Banner (1954) discussed the distribution of two species of Gnathophausia from collections made off the California coast by the Allan Hancock Foundation. These latter collections involved fewer than 30 specimens of Gnathophausia and were taken from shallower levels than those sampled by the midwater trawl.

The development of the midwater trawl at the Scripps Institution has produced a rich collection of bathypelagic specimens, particularly from the eastern Pacific Ocean area. A total of 400 specimens of Gnathophausia were availa- 


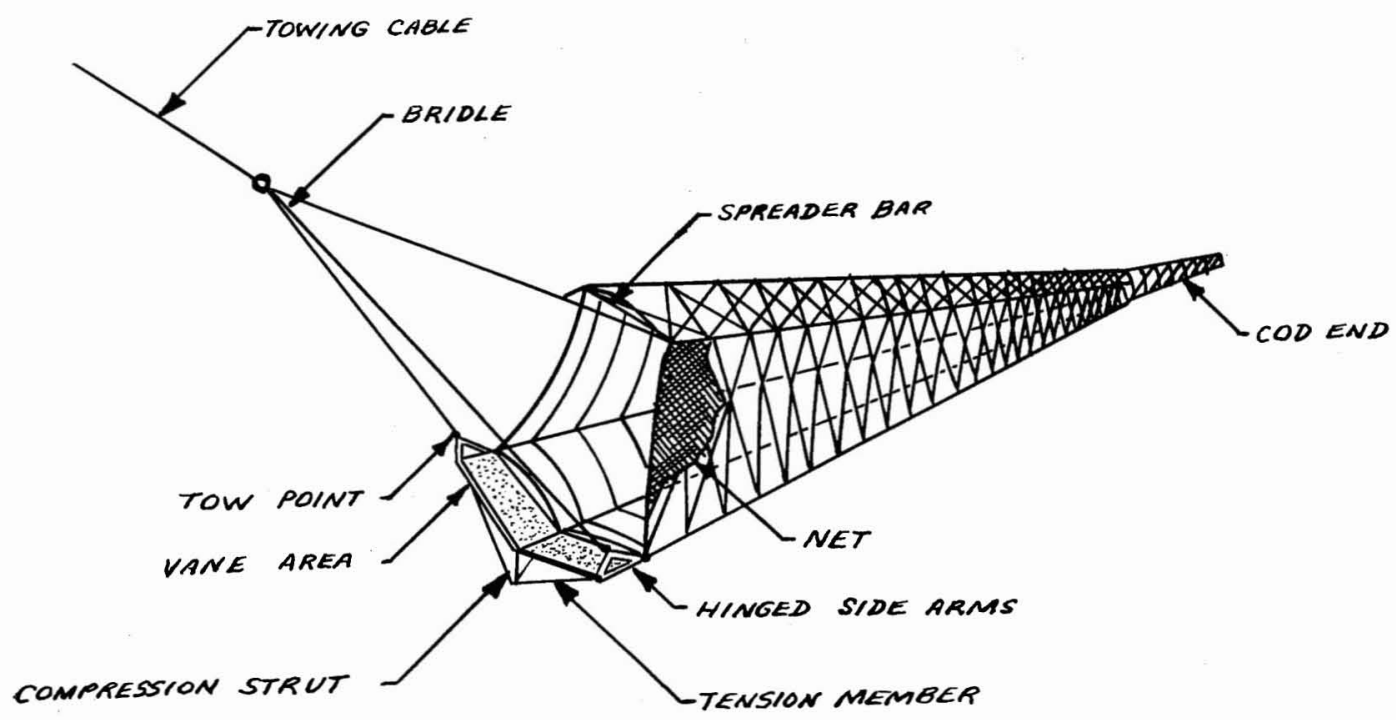

FIG. 1. The Isaacs-Kidd Midwater Trawl. (From SIO Oceanographic Equipment Report, 1953.)

ble for study from the Scripps 1950-53 collections.

In all eight species of Gnathophausia are recognized: G. ingens (Dohrn), G. gigas Willemoes-Suhm, G. gracilis W-Suhm, G. zoea WSuhm, G. elegans G. O. Sars, G. longispina G. O. Sars, G: affinis G. O. Sars, and G. scapularis Ortmann. Of these eight species, four have been identified in the midwater trawl hauls from the Scripps 1950-53 collections in the eastern Pacific. They are G. ingens, G. gigas, G. gracilis, and $G$. zoea.

\section{SYSTEMATIC REVIEW AND MORPHOLOGY}

Since the time of Boas' early report (1883) the mysidaceans have been separated from the euphausiaceans into two distinct orders of the crustacean subclass Malacostraca. These two groups had previously been joined in the order Schizopoda (now abandoned) of Latreille (1817). Hansen (1893) and Calman (1904) further agreed with Boas in separating the two groups, allying the Euphausiacea with the Decapoda in the tribe Eucarida and allying the Mysidacea with the orders Cumacea, Tanaidacea, Isopoda, and Amphipoda in the division Peracarida. An excellent review of the historical systematics and nomenclature of the Mysidacea in relation to other crustacean groups appears in Tattersall and Tattersall (1951), and the reader is referred to this work for the detailed and complete summary.

\section{KEY TO SUBORDERS OF MYSIDACEA ${ }^{2}$}

1. Branchiae (podobranchiae) present on some or all of the thoracic limbs. Marsupium of seven pairs of brood lamellae. Pleopods in both sexes with both rami multiarticulate and natatory; none secondarily modified in the male. No statocyst on endopod of uropod.

LOPHOGASTRIDA

2. Branchiae (podobranchiae) absent. Marsupium generally of fewer than seven pairs of brood lamellae. Pleopods of male natatory or reduced, one or more pairs usually modified as accessory copulatory organs; pleopods of female reduced to simple undivided plates, not natatory. Statocyst usually present on endopod of uropod. . . . . . . MYSIDA

The suborder Lophogastrida, with which we are concerned in the study of Gnathophausia, is divided into two families: (1) the Lophogastridae containing five genera, Lophogaster, Paralophogaster, Chalaraspidum, Ceratolepis, and Gnathophausia; and (2) the Eucopiidae with the single genus Eucopia.

\footnotetext{
${ }^{2}$ From Tattersall and Tattersall, 1951.
} 


\section{KEY TO THE THREE MOST COMMON GENERA OF THE SUBORDER LOPHOGASTRIDA ${ }^{3}$}

1. Branchiae present on all or some of the thoracic limbs. Pleopods well developed in both sexes, natatory, unmodified. No statocyst. Marsupium with seven pairs of brood lamellae (oostegites). . . . . . . . 2

2. Pleural plates of abdominal somites distinct and moderately well developed. . . . . 3

$2^{\prime}$. No pleural plates on abdominal somites. Outer margin of scale naked. Telson entire. . . . . . . . . . . . Eucopia

3. Exopod of uropod divided by a suture near the apex. Maxillules with endopod in the form of a reflexed two-segmented palp. . . .. . . . . . . . Gnatbophausia

$3^{\prime}$. Exopod of uropod undivided; outer margin naked and ending in a tooth. Maxillules without endopod. Antennal scale heartshaped, outer margin serrated . Lophogaster

\section{Distinguisbing Characteristics}

of the Genus Gnathophausia ${ }^{4}$

1. CARAPACE: Rather large, only loosely covering the trunk for most of its length, and exteriorly provided with raised longitudinal keels. Posterior part of carapace usually drawn out dorsally into a posteriorly pointing spine (more pronounced in younger than in mature specimens).

2. ROSTRUM: Elongated and spiniform.

3. ANTENNULE: Antennular peduncle short and thick, outer flagellum greatly produced.

4. ANTENNA: Antennal scale of somewhat varying form in different species.

5. EYES: Eyes well-developed with a small papilla issuing from the stalk anteriorly.

6. MAXILlule: Posteriorly recurved palp on maxillule armed with long setae especially at distal end.

7. MAXILla: Third segment has a long, well-chitinized lobe which is incised right to its

\footnotetext{
${ }^{3}$ From Tattersall and Tattersall, 1951.

'Compiled from Sars, 1885; Fage, 1941; and Tattersall and Tattersall, 1951.
}

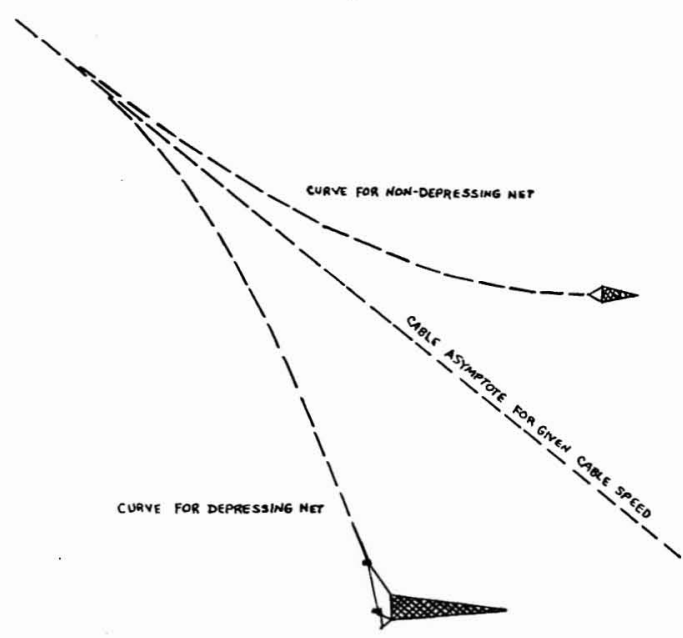

FIG. 2. Comparison of Isaacs-Kidd Midwater Trawl with non-depressing net. (From SIO Oceanographic Equipment Report, 1953.)

base forming two long, slender, finger-like processes armed with setae only at their tips. On the outer side of the coxa there is a brightly pigmented papilla which bears the opening of a gland producing a luminous secretion.

8. THORACIC LIMBS: Maxillipeds with exopodites either very small or entirely lacking. Remaining thoracic limbs nearly uniform, all provided with exopods.

9. BRANCHIAE: Those on second to seventh thoracic limbs divided into four branches with irregularly lobed pinnules. Branchiae on eighth thoracic limb rudimentary.

10. THORACIC STERNITES: In males each thoracic sternite bears a tubercle.

11. ABDOMEN: Abdominal segments narrow with small bilobed epimera. A transverse groove dividing the sixth abdominal segment.

12. UROPODS: External branch broader than internal branch with two segments on external branch.

13. TELSON: Large, constricted near the base; two long keels present on dorsal surface; lateral margins armed with spines arranged in series of larger spines with smaller ones between; apex armed with two strong, curved spines connected at the base to form a backwardly directed crescent.

14. MARSUPIUM: Seven pairs of oostegites. 


\section{KEY TO THE SPECIES OF THE GENUS Gnathophausia ${ }^{5}$}

a. Antennal scale small, not jointed, no strong rib terminating in a spine on outer margin; outer margin serrate. Epimera of sixth abdominal segment united ventrally, forming together a cordiform, concave plate, incised at apex. Dorsal keel of carapace interrupted. Lower lateral keel not curving upward behind, but terminating in a spine at the postero-inferior angle. Branchiostegal lobe generally with a well developed spine (sometimes obsolete). Maxillipeds with a small exopodite.

b. Both lappets of the epimera of the second to fifth abdominal segments pointed and spiniform. Antennal scale subovate, apex shortly pointed. . . . . . . . ingens

$b^{\prime}$. Anterior lappet of the epimera of the first to the fifth abdominal segments small, rounded; posterior lappet pointed and spiniform. Antennal scale sublanceolate, tapering to a sharp spiniform point. . . . . . . . . . . . . . . . . . gigas

$a^{\prime}$. Antennal scale large, of usual form, jointed at the extremity, outer margin formed by a strong rib terminating in a spine. Epimera of sixth abdominal segment not confluent ventrally.

b. Lower lateral keel of carapace not curving up behind, but terminating in a spine on the postero-inferior angle of the carapace. Median keel of carapace interrupted, with spiniform serrations. Median line of abdominal segments with strong spines. Upper lateral keel of carapace wanting. Two epimeral spines on each side of the anterior section of the sixth abdominal segment. Maxillipeds with exopodite. . . . . . . . . gracilis

$\mathrm{b}^{\prime}$. Lower lateral keel of carapace curving up behind; no spine at postero-inferior angle of carapace. Median keel of carapace not interrupted, without spiniform serrations. Median line of abdominal segments-if armed at all-only with posteriorly projecting, small spines. Upper lateral keel of carapace present, very rarely wanting. Maxillipeds without exopodite.

c. Two epimeral spines on each side of anterior section of sixth abdominal segment. Upper lateral keel of carapace present. Antennal spine obsolete. Branchiostegal lobe with a well-marked triangular spine. Spine of outer margin of antennal scale projecting considerably beyond terminal lobe, serrated on both margins. . . longispina

$c^{\prime}$. One epimeral spine on each side of anterior section of sixth abdominal segment. Antennal spine more or less distinct. Branchiostegal lobe without spine, generally rounded, rarely angular. Spine of outer margin of antennal scale not, or only slightly, projecting beyond terminal lobe.

d. Upper lateral keel of carapace present.

e. Abdominal segments dorsally slightly keeled, with small, posteriorly projecting spines. Epimera of five anterior abdominal segments pointed posteriorly. Branchiostegal lobe rounded.

f. Carapace not suddenly constricted anteriorly and forming no shoulder. Branchiostegal lobes moderately developed. . . zoea

$\mathrm{f}^{\prime}$. Carapace suddenly constricted anteriorly, forming a distinct shoulder in front of the anterior ends of the upper lateral keels. Branchiostegal lobe greatly expanded. . . . . . . scapularis

\footnotetext{
${ }^{5}$ Based on Ortmann, 1906, with alterations.
} 
$e^{\prime}$. Abdominal segments dorsally not keeled, without spines. Epimera of the five anterior abdominal segments rounded posteriorly. Branchiostegal lobe slightly angular. . . . . . . . . . . . affinis

$d^{\prime}$. Upper lateral keel of carapace wanting. Branchiostegal lobe rounded or angular, but without spine. Abdominal segments dorsally without keel, but posteriorly with a small, depressed triangular projection. Epimera of five anterior abdominal segments ending in small points posteriorly. . elegans

\section{SIZE AND SEXUAL MATURITY}

Gnathophausia ingens (Dohrn 1870)

Figs. 3 and 4

Gnathophausia calcarata G. O. Sars, 1885 bengalensis Wood-Mason, 1891

“ doryopbora Illig, 1906

A total of 204 specimens of Gnathophausia ingens were identified from the Scripps 195053 collections, consisting of 112 females, 23 males, and 69 juveniles, ranging in size from $25 \mathrm{~mm}$ to $139 \mathrm{~mm}$ body length (Table 1 ). The 15 largest specimens (all greater than $110 \mathrm{~mm}$ as measured from the level of the eyes to the end of the telson) are listed in Table 2. The body length is normally measured from the base of the rostrum at the level of the eyes to the end of the telson. However, in many cases in past literature, measurements are given which include the rostrum. This latter measurement of total length is less reliable because of dam-
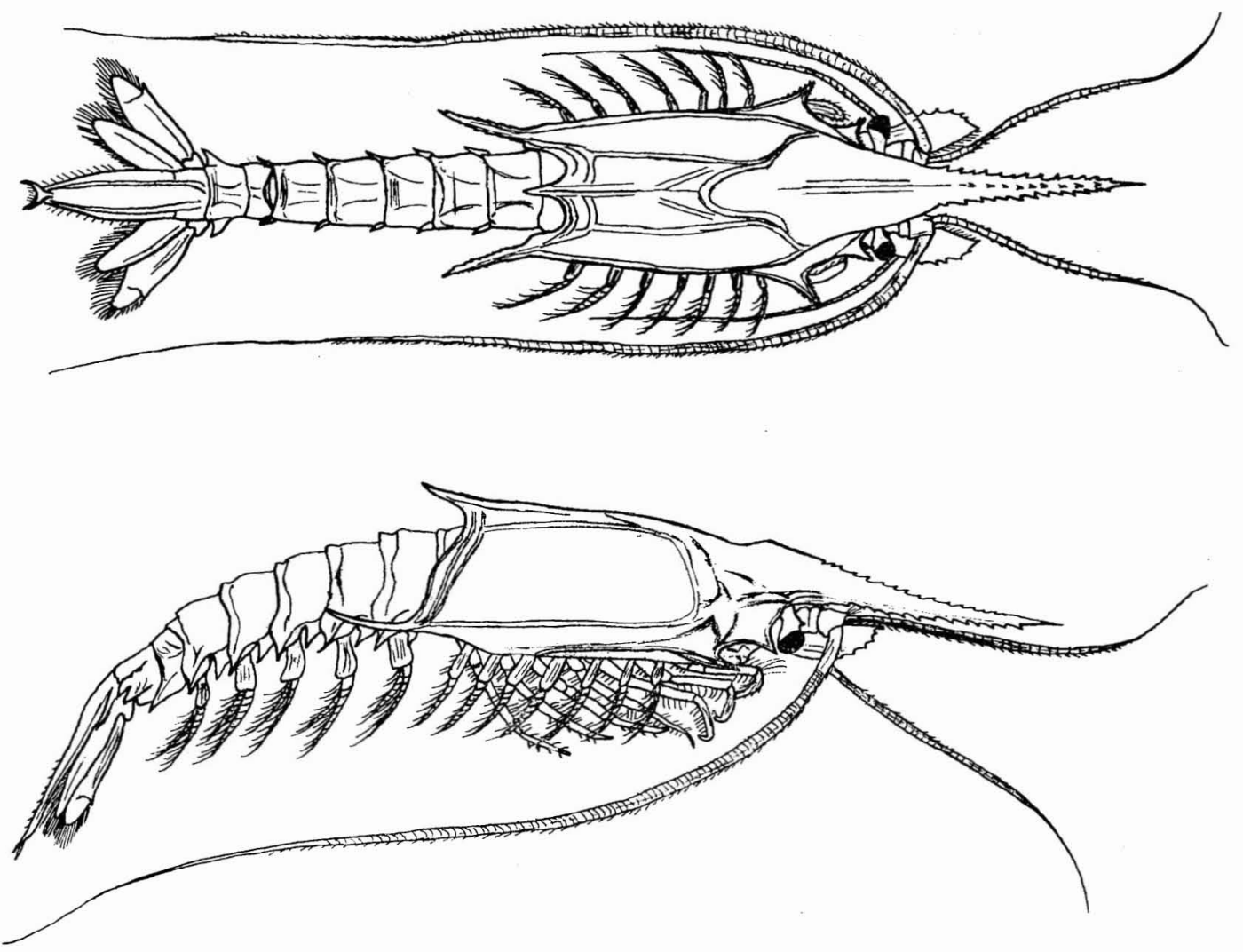

FIG. 3. Gnatbopbausia ingens, young specimen of $98 \mathrm{~mm}$ total length. (From Sars, 1885.) 
TABLE 1

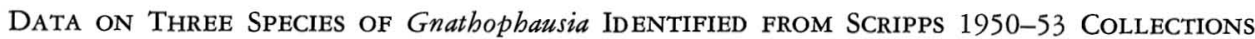

\begin{tabular}{|c|c|c|c|c|c|c|c|c|c|c|c|c|c|c|c|}
\hline \multirow{4}{*}{ STATION } & \multirow{4}{*}{ DATE } & \multirow{3}{*}{\multicolumn{2}{|c|}{ POSITION }} & \multirow{4}{*}{$\begin{array}{l}\text { DEPTH } \\
\text { OF } \\
\text { HAUL } \\
\text { (meters) }\end{array}$} & \multirow{4}{*}{$\begin{array}{l}\text { BOTTOM } \\
\text { DEPTH } \\
\text { (meters) }\end{array}$} & \multirow{4}{*}{ TIME } & \multicolumn{9}{|c|}{ NUMBER AND SIZE (mm) OF INDIVIDUALS } \\
\hline & & & & & & & \multirow{2}{*}{\multicolumn{3}{|c|}{$\begin{array}{l}\text { Gnathophausia ingens } \\
\text { Small Medium Large }\end{array}$}} & \multirow{3}{*}{\multicolumn{3}{|c|}{$\begin{array}{l}\text { Gnathophausia gigas } \\
\text { Small Medium Large } \\
<60 \quad 60-100>100\end{array}$}} & \multirow{3}{*}{\multicolumn{3}{|c|}{$\begin{array}{l}\text { Gnatbophausia gracilis } \\
\text { Small Medium Large } \\
<60 \quad 60-100>100\end{array}$}} \\
\hline & & & & & & & & & & & & & & & \\
\hline & & & & & & & & & & & & & & & \\
\hline $\mathrm{H} 50-261$ & $10 / 26 / 50$ & $32^{\circ} 30^{\prime} \mathrm{N}$ & $117^{\circ} 25^{\prime} \mathrm{W}$ & 668 & 1097 & 2330 & 1 & 2 & - & - & - & - & - & 二 & - \\
\hline $\mathrm{H} 50-263$ & $11 / 7 / 50$ & $31^{\circ} 52^{\prime} \mathrm{N}$ & $119^{\circ} 58^{\prime} \mathrm{W}$ & 2743 & 3840 & ? & 2 & 4 & - & - & - & - & 2 & 4 & - \\
\hline $\mathrm{H} 50-269$ & $11 / 16 / 50$ & $\begin{array}{l}32^{\circ} 30.5^{\prime}- \\
32^{\circ} 27.75^{\prime} \mathrm{N}\end{array}$ & $\begin{array}{l}117^{\circ} 27.5^{\prime}- \\
117^{\circ} 27.0^{\prime} \mathrm{W}\end{array}$ & 750 & $?$ & $1350-1450$ & 6 & 10 & 1 & - & - & - & - & - & - \\
\hline $\mathrm{H} 50-276$ & $11 / 30 / 50$ & $32^{\circ} 32^{\prime} \mathrm{N}$ & $117^{\circ} 22^{\prime} \mathrm{W}$ & 366 & 732 & $1626-1855$ & 6 & 3 & - & - & - & - & - & - & - \\
\hline $\mathrm{H} 50-277$ & $12 / 1 / 50$ & $\mid \begin{array}{l}32^{\circ} 34^{\prime}- \\
32^{\circ} 19.5^{\prime} \mathrm{N}\end{array}$ & $\begin{array}{l}117^{\circ} 24.5^{\prime}- \\
117^{\circ} 20.5^{\prime} \mathrm{W}\end{array}$ & 732 & 1235 & $0835-1300$ & 5 & 5 & 3 & 一 & - & - & 1 & - & - \\
\hline H51-45 & $2 / 15 / 51$ & $\begin{array}{l}32^{\circ} 26.8^{\prime}- \\
32^{\circ} 22.0^{\prime} \mathrm{N}\end{array}$ & $\begin{array}{l}117^{\circ} 30.2^{\prime}- \\
117^{\circ} 24.9^{\prime} \mathrm{W}\end{array}$ & 799 & 1252 & $1430-1845$ & 3 & 6 & 4 & 一 & - & - & 8 & 1 & - \\
\hline H51-70 & $3 / 15 / 51$ & $\begin{array}{l}31^{\circ} 49^{\prime}- \\
31^{\circ} 34^{\prime} \mathrm{N}\end{array}$ & $\begin{array}{l}117^{\circ} 30.5^{\prime}- \\
117^{\circ} 34.0^{\prime} \mathrm{W}\end{array}$ & 635 & $\begin{array}{c}1372- \\
732\end{array}$ & $1704-2130$ & 4 & 7 & - & - & - & - & - & - & - \\
\hline H51-74 & $3 / 17 / 51$ & $\begin{array}{l}28^{\circ} 57.5^{\prime}- \\
29^{\circ} 06.3^{\prime} \mathrm{N}\end{array}$ & $\begin{array}{c}118^{\circ} 11: 8^{\prime} \mathrm{W}- \\
?\end{array}$ & 914 & 2560 & 1550 & - & 1 & 2 & - & 1 & - & 1 & 4 & - \\
\hline H51-75 & $3 / 17 / 51$ & $\begin{array}{l}29^{\circ} 02^{\prime}- \\
28^{\circ} 55^{\prime} \mathrm{N}\end{array}$ & $\begin{array}{l}118^{\circ} 08.5^{\prime}- \\
118^{\circ} 03.6^{\prime} \mathrm{W}\end{array}$ & 366 & 3658 & $1930-2130$ & 2 & 1 & - & - & 一 & - & 一 & - & - \\
\hline H51-76 & $3 / 17 / 51$ & $\begin{array}{l}28^{\circ} 51.6^{\prime}- \\
28^{\circ} 45.3^{\prime} \mathrm{N}\end{array}$ & $\begin{array}{l}118^{\circ} 01.5^{\prime}- \\
117^{\circ} 56.0^{\prime} \mathrm{W}\end{array}$ & 366 & 3658 & $2215-0015$ & 5 & 1 & 一 & - & - & - & - & - & 一 \\
\hline H51-77 & $3 / 18 / 51$ & $\begin{array}{l}28^{\circ} 43.5^{\prime}- \\
28^{\circ} 34.5^{\prime} \mathrm{N}\end{array}$ & $\begin{array}{l}117^{\circ} 55^{\prime}- \\
117^{\circ} 44^{\prime} \mathrm{W}\end{array}$ & 1491 & 3658 & $0045-0925$ & 一 & 1 & - & 1 & 4 & 一 & 4 & 11 & 2 \\
\hline H51-82 & $3 / 19 / 51$ & $\begin{array}{l}27^{\circ} 33^{\prime}- \\
27^{\circ} 17^{\prime} \mathrm{N}\end{array}$ & $\begin{array}{l}117^{\circ} 15^{\prime}- \\
117^{\circ} 12^{\prime} \mathrm{W}\end{array}$ & 1810 & 3658 & $0921-1515$ & 一 & 一 & - & - & 一 & 一 & 一 & 4 & - \\
\hline H51-84 & $3 / 20 / 51$ & $\begin{array}{l}25^{\circ} 28.3^{\prime}- \\
25^{\circ} 34.0^{\prime} \mathrm{N}\end{array}$ & $\begin{array}{l}115^{\circ} 28.6^{\prime}- \\
115^{\circ} 05.0^{\prime} \mathrm{W}\end{array}$ & 914 & 3658 & $1232-1706$ & 1 & 1 & 1 & 2 & - & 一 & 2 & 8 & 1 \\
\hline H51-85 & $3 / 20 / 51$ & $\begin{array}{l}25^{\circ} 34.0^{\prime}- \\
25^{\circ} 31.3^{\prime} \mathrm{N}\end{array}$ & $\begin{array}{l}115^{\circ} 05.0^{\prime}- \\
115^{\circ} 16.2^{\prime} \mathrm{W}\end{array}$ & 549 & 3658 & $1825-2155$ & 一 & - & 2 & - & - & 一 & - & - & - \\
\hline H51-90 & $\begin{array}{l}3 / 21 \& \\
22 / 51\end{array}$ & $\begin{array}{l}25^{\circ} 44^{\prime}- \\
25^{\circ} 52^{\prime} \mathrm{N}\end{array}$ & $\begin{array}{l}114^{\circ} 52^{\prime}- \\
114^{\circ} 40^{\prime} \mathrm{W}\end{array}$ & 2213 & 3658 & $2142-0930$ & - & 1 & 1 & 一 & - & 1 & - & 3 & 2 \\
\hline H51-91 & $3 / 22 / 51$ & $\begin{array}{l}25^{\circ} 52^{\prime}- \\
26^{\circ} 00^{\prime} \mathrm{N}\end{array}$ & $\begin{array}{l}114^{\circ} 40^{\prime}- \\
114^{\circ} 24^{\prime} \mathrm{W}\end{array}$ & 2012 & 4023 & $1056-1830$ & - & - & - & - & 1 & - & 2 & 8 & 1 \\
\hline H51-146 & $4 / 19 / 51$ & $\begin{array}{l}32^{\circ} 34^{\prime}- \\
32^{\circ} 26.5^{\prime} \mathrm{N}\end{array}$ & $\begin{array}{l}117^{\circ} 28.5^{\prime}- \\
117^{\circ} 24.0^{\prime} \mathrm{W}\end{array}$ & 640 & 1170 & $1115-1440$ & 2 & - & - & - & 一 & - & - & - & 一 \\
\hline H51-148 & $4 / 20 / 51$ & $\begin{array}{l}32^{\circ} 40.7^{\prime}- \\
32^{\circ} 46.0^{\prime} \mathrm{N}\end{array}$ & $\begin{array}{l}117^{\circ} 35.5^{\prime}- \\
117^{\circ} 42.0^{\prime} \mathrm{W}\end{array}$ & 1006 & 1006 & $0515-0915$ & 2 & 1 & - & 一 & - & 一 & - & - & - \\
\hline $\mathrm{H} 51-160$ & $4 / 26 / 51$ & $\begin{array}{l}32^{\circ} 51^{\prime}- \\
32^{\circ} 58^{\prime} \mathrm{N}\end{array}$ & $\begin{array}{l}118^{\circ} 57^{\prime} \mathrm{W} \\
118^{\circ} 18^{\prime}-\end{array}$ & 549 & 914 & $1519-1745$ & 7 & 2 & 一 & 一 & - & 一 & - & - & 一 \\
\hline
\end{tabular}




\begin{tabular}{|c|c|c|c|c|c|c|c|c|c|c|c|c|c|c|c|}
\hline H51-161 & $\begin{array}{l}4 / 27- \\
28 / 51\end{array}$ & $\mid \begin{array}{l}30^{\circ} 00^{\prime}- \\
29^{\circ} 39^{\prime} \mathrm{N}\end{array}$ & $\begin{array}{l}121^{\circ} 00^{\prime}- \\
121^{\circ} 09^{\prime} \mathrm{W}\end{array}$ & 2085 & 3658 & $2220-0850$ & 1 & - & - & - & - & 1 & 1 & 2 & - \\
\hline H51-162 & $4 / 28 / 51$ & $\begin{array}{l}29^{\circ} 35^{\prime}- \\
? 9^{\circ} 33^{\prime} \mathrm{N}\end{array}$ & $\begin{array}{l}121^{\circ} 06^{\prime}- \\
121^{\circ} 15^{\prime} \mathbb{W}\end{array}$ & 914 & 3658 & 0940-1600 & 1 & 6 & 4 & 一 & - & - & 1 & 4 & - \\
\hline H51-167 & $5 / 10 / 51$ & $\begin{array}{l}31^{\circ} 42^{\prime}- \\
32^{\circ} 49^{\prime} \mathrm{N}\end{array}$ & $\begin{array}{l}117^{\circ} 35^{\prime}- \\
117^{\circ} 43^{\prime} \mathrm{W}\end{array}$ & 549 & 914 & $1830-2115$ & 12 & 20 & - & - & - & - & - & 一 & - \\
\hline H51-187 & $5 / 21 / 51$ & $\begin{array}{l}32^{\circ} 54^{\prime}- \\
33^{\circ} 02.5^{\prime} \mathrm{N}\end{array}$ & $\begin{array}{l}117^{\circ} 47^{\prime}- \\
117^{\circ} 56^{\prime} \mathrm{W}\end{array}$ & 274 & 914 & $2155-2358$ & 3 & - & - & - & - & - & - & - & - \\
\hline H51-278 & $7 / 27 / 51$ & $\begin{array}{l}32^{\circ} 31.2^{\prime}- \\
32^{\circ} 28.4^{\prime} \mathrm{N}\end{array}$ & $\begin{array}{l}117^{\circ} 45.6^{\prime}- \\
117^{\circ} 44.6^{\prime} \mathrm{W}\end{array}$ & 320 & $\begin{array}{l}1390- \\
1463\end{array}$ & 0100-0251 & 1 & 2 & - & - & - & - & - & - & - \\
\hline $\mathrm{H} 51-355$ & $8 / 6 / 51$ & $40^{\circ} 22^{\prime} \mathrm{N}$ & $139^{\circ} 23^{\prime} \mathrm{W}$ & 3400 & 4206 & $0020-0930$ & - & - & - & - & - & 1 & - & - & - \\
\hline H51-357 & $8 / 8 / 51$ & $40^{\circ} 37^{\prime} \mathrm{N}$ & $143^{\circ} 25^{\prime} \mathrm{W}$ & 3987 & 4536 & $0007-0710$ & - & 一 & - & 1 & - & - & - & - & - \\
\hline H51-361 & $8 / 16 / 51$ & $51^{\circ} 35^{\prime} \mathrm{N}$ & $150^{\circ} 00^{\prime} \mathrm{W}$ & $\begin{array}{l}1100- \\
1600\end{array}$ & 4755 & $0820-1333$ & - & 一 & - & 6 & - & - & - & - & - \\
\hline H51-362 & $\begin{array}{l}8 / 16- \\
17 / 51\end{array}$ & $52^{\circ} 48^{\prime} \mathrm{N}$ & $150^{\circ} 10^{\prime} \mathrm{W}$ & 1020 & 1225 & $2320-0325$ & - & 一 & - & 16 & - & - & - & 一 & - \\
\hline H51-364 & $8 / 21 / 51$ & $53^{\circ} 35^{\prime} \mathrm{N}$ & $144^{\circ} 20^{\prime} \mathrm{W}$ & 1280 & $\begin{array}{l}988- \\
1372\end{array}$ & $0605-0815$ & - & 一 & - & 2 & - & - & - & - & - \\
\hline H51-366 & $8 / 24 / 51$ & $56^{\circ} 15^{\prime} \mathrm{N}$ & $144^{\circ} 50^{\prime} \mathrm{W}$ & 2972 & 3658 & $0300-0831$ & - & - & - & 7 & 2 & 1 & - & - & - \\
\hline H51-367 & $8 / 25 / 51$ & $56^{\circ} 20^{\prime} \mathrm{N}$ & $145^{\circ} 20^{\prime} \mathrm{W}$ & 603 & 768 & $0400-0530$ & - & - & - & 5 & - & - & 一 & - & - \\
\hline H51-371 & $\begin{array}{l}9 / 5- \\
6 / 51\end{array}$ & $\begin{array}{l}48^{\circ} 58.3^{\prime}- \\
48^{\circ} 37.4^{\prime} \mathrm{N}\end{array}$ & $\begin{array}{l}157^{\circ} 49.8^{\prime}- \\
157^{\circ} 29.0^{\prime} \mathbf{W}\end{array}$ & $\begin{array}{l}4023- \\
4389\end{array}$ & 4883 & $1800-0505$ & - & - & - & 8 & 1 & 1 & - & - & - \\
\hline H51-373 & $\begin{array}{l}9 / 9- \\
10 / 51\end{array}$ & $\begin{array}{l}41^{\circ} 20.2^{\prime}- \\
41^{\circ} 12.5^{\prime} \mathrm{N}\end{array}$ & $\begin{array}{l}155^{\circ} 13.3^{\prime}- \\
155^{\circ} 11.0^{\prime} \mathrm{W}\end{array}$ & 2140 & $?$ & $1650-0355$ & - & 一 & - & 2 & 1 & - & - & - & - \\
\hline H51-375 & $9 / 15 / 51$ & $\begin{array}{l}31^{\circ} 54.3^{\prime}- \\
31^{\circ} 36.5^{\prime} \mathrm{N}\end{array}$ & $\begin{array}{l}152^{\circ} 21.6^{\prime}- \\
152^{\circ} 03.6^{\prime} \mathrm{W}\end{array}$ & 3274 & 5121 & $0505-1650$ & 1 & 1 & - & - & 1 & - & 1 & 1 & - \\
\hline H51-376 & $\begin{array}{l}9 / 18- \\
19 / 51\end{array}$ & $\begin{array}{l}30^{\circ} 25^{\prime}- \\
30^{\circ} 31^{\prime} \mathrm{N}\end{array}$ & $\begin{array}{l}145^{\circ} 08^{\prime}- \\
144^{\circ} 53.2^{\prime} \mathrm{W}\end{array}$ & 402 & 4755 & $2105-0225$ & 2 & 一 & - & - & - & - & - & - & 一 \\
\hline H51-377 & $\begin{array}{l}9 / 23- \\
24 / 51\end{array}$ & $\begin{array}{l}30^{\circ} 01^{\prime}- \\
33^{\circ} 09^{\prime} \mathrm{N}\end{array}$ & $\begin{array}{l}127^{\circ} 39^{\prime}- \\
127^{\circ} 34^{\prime} \mathrm{W}\end{array}$ & 3914 & 4755 & $1630-1030$ & 一 & 1 & 一 & - & - & - & 2 & 3 & - \\
\hline H51-392 & $11 / 2 / 51$ & $\begin{array}{l}32^{\circ} 39.3^{\prime}- \\
32^{\circ} 49.4^{\prime} \mathrm{N}\end{array}$ & $\begin{array}{l}117^{\circ} 37.2^{\prime}- \\
117^{\circ} 45.2^{\prime} \mathrm{W}\end{array}$ & $\begin{array}{l}914- \\
1097\end{array}$ & $?$ & $1335-1812$ & 9 & 2 & - & - & - & - & 2 & 2 & - \\
\hline H51-397 & $11 / 3 / 51$ & $\begin{array}{l}32^{\circ} 42.7^{\prime}- \\
32^{\circ} 36.4^{\prime} \mathrm{N}\end{array}$ & $\begin{array}{l}117^{\circ} 37.2^{\prime}- \\
117^{\circ} 36.4^{\prime} \mathrm{W}\end{array}$ & $\begin{array}{l}823- \\
1042\end{array}$ & 1170 & $0655-1053$ & 5 & 1 & - & 一 & - & - & 4 & - & - \\
\hline H51-406 & $\begin{array}{l}11 / 29 \\
30 / 51\end{array}$ & $\begin{array}{l}27^{\circ} 17.6^{\prime}- \\
26^{\circ} 56.8^{\prime} \mathrm{N}\end{array}$ & $\begin{array}{l}117^{\circ} 04.9^{\prime}- \\
117^{\circ} 00.9^{\prime} \mathrm{W}\end{array}$ & 2926 & 3658 & $1910-0750$ & 2 & 1 & - & - & - & - & 5 & 2 & - \\
\hline H52-10 & $2 / 26 / 52$ & $32^{\circ} 37^{\prime} \mathrm{N}$ & $117^{\circ} 37^{\prime} \mathrm{W}$ & 960 & 1097 & $?$ & - & 4 & - & - & - & - & - & 一 & - \\
\hline H52-13 & $2 / 27 / 52$ & $32^{\circ} 37^{\prime} \mathrm{N}$ & $117^{\circ} 37^{\prime} \mathrm{W}$ & $?$ & 1225 & $1915-2400$ & - & 1. & - & 一 & - & - & - & - & 一 \\
\hline H52-15 & $2 / 28 / 52$ & $32^{\circ} 17.6^{\prime} \mathrm{N}$ & $117^{\circ} 37^{\prime} \mathrm{W}$ & $?$ & 1207 & $0835-1300$ & - & 1 & 1 & - & - & - & - & - & 一 \\
\hline H52-32 & $3 / 21 / 52$ & $32^{\circ} 35.5^{\prime} \mathrm{N}$ & $\begin{array}{l}117^{\circ} 28.2^{\prime}- \\
117^{\circ} 32.2^{\prime} \mathrm{W}\end{array}$ & 732 & 1189 & $1326-1415$ & 3 & 7 & 1 & - & - & - & - & - & - \\
\hline $\mathrm{H} 52-40$ & $4 / 2 / 52$ & $\begin{array}{l}33^{\circ} 46^{\prime}- \\
33^{\circ} 48.7^{\prime} \mathrm{N}\end{array}$ & $\begin{array}{l}119^{\circ} 34.3^{\prime}- \\
119^{\circ} 39.5^{\prime} \mathrm{W}\end{array}$ & 1463 & 1829 & $1207-1700$ & 1 & 一 & - & - & - & - & - & - & - \\
\hline H52-309 & $5 / 23 / 52$ & $\begin{array}{l}17^{\circ} 48^{\prime}- \\
17^{\circ} 42^{\prime} \mathrm{N}\end{array}$ & $\begin{array}{l}124^{\circ} 07^{\prime}- \\
124^{\circ} 05.1^{\prime} \mathrm{W}\end{array}$ & 1105 & $\begin{array}{l}4271- \\
1920\end{array}$ & 0700-1215 & - & 1 & 3 & - & - & - & - & 7 & 一 \\
\hline
\end{tabular}




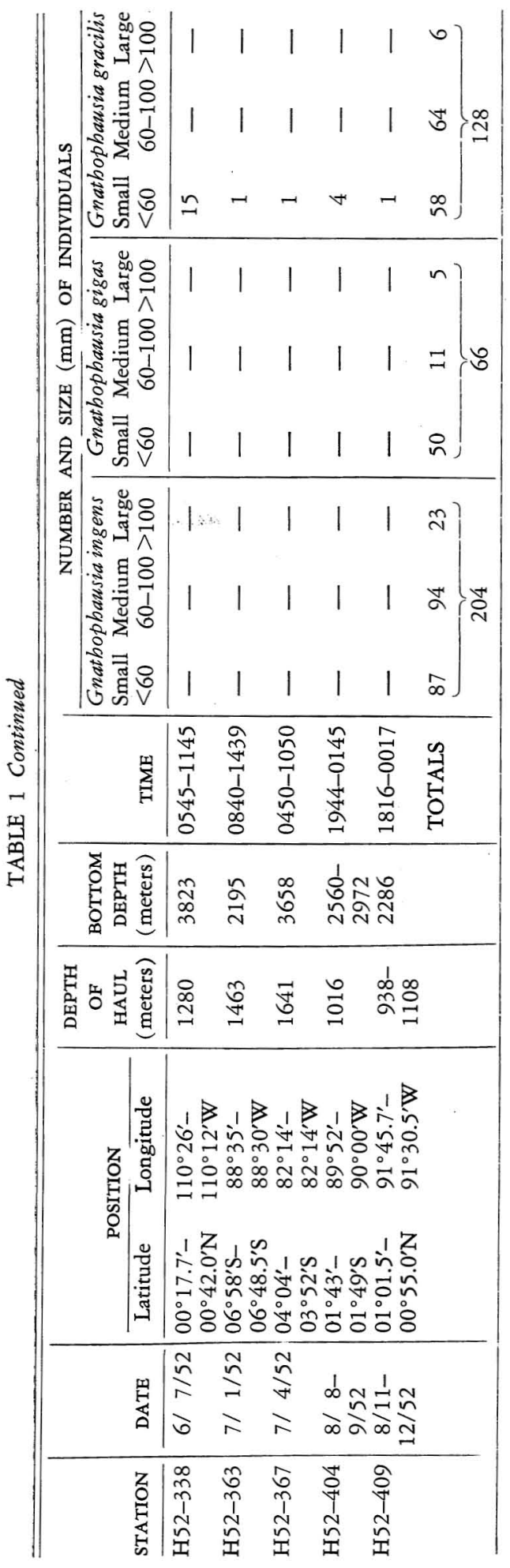

age or breakage to the rostrum which frequently occurs during sampling and preservation of the specimens.

The largest specimen of $G$. ingens on record is a giant female measuring $350 \mathrm{~mm}$ total length (from the tip of the rostrum to the end of the telson). This specimen was captured with the Isaacs-Kidd Midwater Trawl in 1955 on the Scripps Institution of Oceanography's Eastropic Expedition in the equatorial Pacific and was described by Clark (1961). This giant specimen is more than $1 \frac{1}{2}$ times larger than the previously reported largest specimen, a male from the Talisman Expedition (Hansen, 1927) with a body length of $185 \mathrm{~mm}$ ( $210 \mathrm{~mm}$ total length including the rostrum) which was taken in the Atlantic Ocean south of the Azores. None of the specimens from the 1950-53 Scripps collections in the eastern Pacific exceeded these lengths. The largest is a male of 139 mm body length (160 mm including the rostrum).

Of the 204 specimens of $G$. ingens examined from the 1950-53 Scripps collections, none of the 112 females possessed a completely developed brood pouch. Although many of the larger specimens possessed oostegites as long as or longer than the thoracic legs, none was completely developed to form a true marsupium containing eggs or embryos.

Only three previous accounts of sexually mature females of this species have been reported. One was described by G. O. Sars (1885) from the Challenger Expedition and measured $157 \mathrm{~mm}$ total length. A second, described by Fage (1941) from the Dana Expedition, measured $140 \mathrm{~mm}$ ( $165 \mathrm{~mm}$ including the rostrum). The oostegites on the latter specimen were clearlv longer than the thoracic legs and measured $50 \mathrm{~mm}$ in length and $18 \mathrm{~mm}$ at their greatest width. The third was the giant female specimen described by Clark (1961).

The criterion used for the determination of sexual maturity in female mysids is the presence of a well developed marsupium. In the case of the males it is more difficult to recognize sexual maturity because of the difficulty in determining when the male genital pore, located on the last thoracic leg, is mature and functional.

The sizes 140 and $157 \mathrm{~mm}$ body length may be considered as the minimum sizes of sexual 

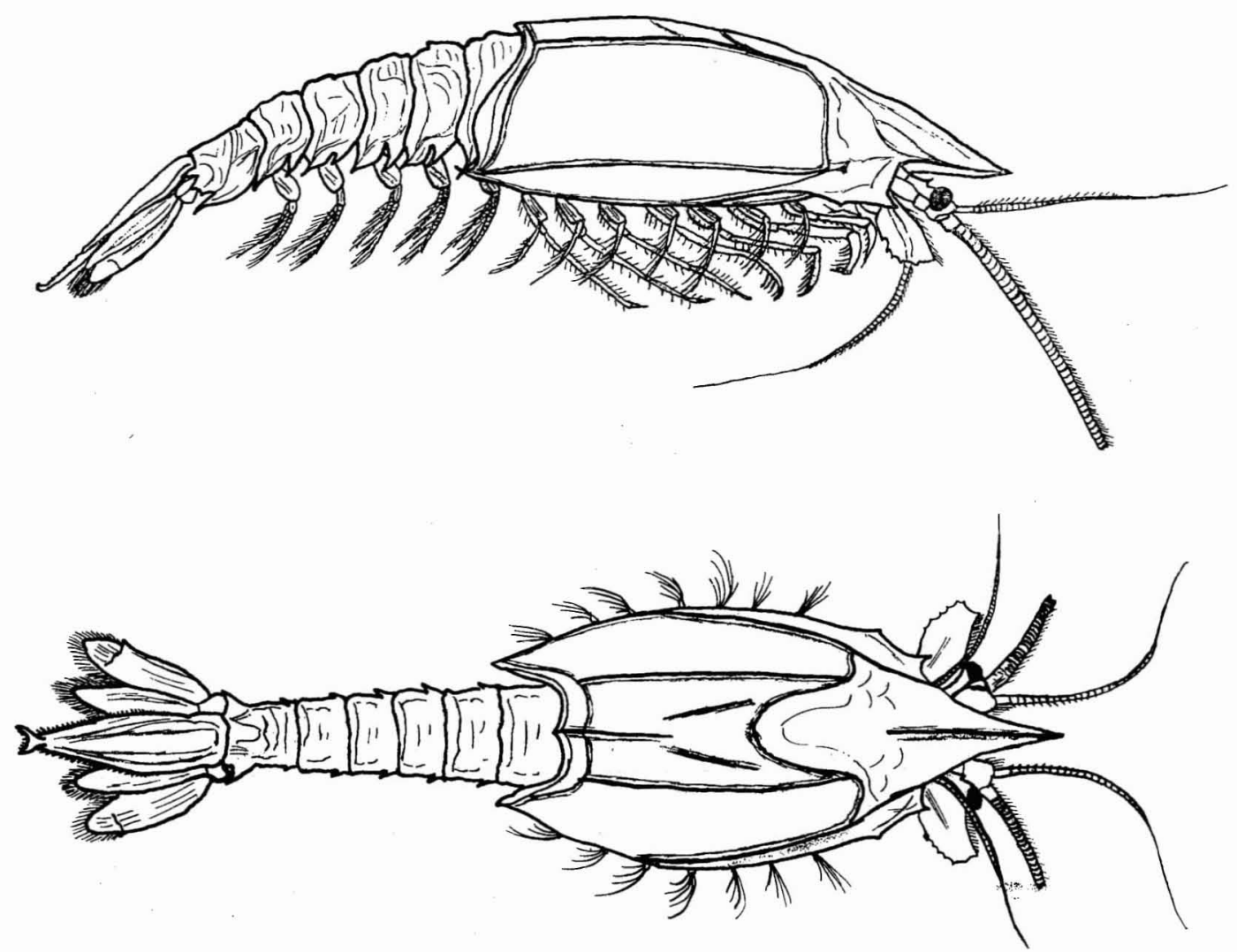

FIG. 4. Gnathophausia ingens, adult female of $157 \mathrm{~mm}$. (From Sars, 1885.)

TABLE 2

Gnatbophausia ingens

SIZE AND LOCATION OF LARgEST SPECIMENS CAPTURED

\begin{tabular}{|c|c|c|c|c|c|}
\hline \multicolumn{2}{|c|}{ SIZE $(\mathrm{mm})$} & \multirow[b]{2}{*}{ SEX } & \multirow[b]{2}{*}{ STATION* } & \multirow{2}{*}{$\begin{array}{c}\text { DEPTH OF } \\
\text { HAUL } \\
\text { (meters) }\end{array}$} & \multirow[b]{2}{*}{$\begin{array}{l}\text { APPROXIMATE } \\
\text { LOCATION* }\end{array}$} \\
\hline $\begin{array}{l}\text { Without } \\
\text { Rostrum }\end{array}$ & $\begin{array}{l}\text { Rostrum } \\
\text { Included }\end{array}$ & & & & \\
\hline 139 & 160 & $\mathbf{M}$ & H51-85 & 549 & off Baja California, Mex. \\
\hline 134 & 155 & M & H52-309 & 1105 & off Southern Mexico \\
\hline 125 & 143 & $\mathrm{~F}$ & H51-162 & 914 & off Baja California, Mex. \\
\hline 123 & 144 & $\mathrm{~F}$ & $\mathrm{H} 52-32$ & 732 & off San Diego, Calif. \\
\hline 123 & 144 & $\mathrm{~F}$ & H52-15 & ? & off San Diego, Calif. \\
\hline 122 & $?$ & $\mathrm{~F}$ & H51-162 & 914 & off Baja California, Mex. \\
\hline 120 & 138 & $\mathbf{F}$ & H50-277 & 732 & off San Diego, Calif. \\
\hline 118 & 137 & $\mathbf{F}$ & $\mathrm{H} 51-90$ & 2213 & off Baja California, Mex. \\
\hline 115 & 138 & $\mathrm{~F}$ & $\mathrm{H} 50-277$ & 732 & off San Diego, Calif. \\
\hline 115 & 134 & $\mathrm{~F}$ & H50-269 & 750 & off San Diego, Calif. \\
\hline 114 & 135 & $\mathrm{~F}$ & H52-309 & 1105 & off Southern Mexico \\
\hline 114 & 134 & $\mathbf{F}$ & H51-85 & 549 & off Baja California, Mex. \\
\hline 113 & 136 & $\mathbf{F}$ & H51-45 & 799 & off San Diego, Calif. \\
\hline 113 & 133 & $\mathrm{~F}$ & $\mathrm{H} 51-45$ & 799 & off San Diego, Calif. \\
\hline 111 & 130 & F & $\mathrm{H} 50-277$ & 732 & off San Diego, Calif. \\
\hline
\end{tabular}

* See Table 1 for exact locations. 
maturity in the case of the female G. ingens. Fage (1941) reports another female from the Dana Expedition, larger than his sexually mature female of $140 \mathrm{~mm}$, measuring $142 \mathrm{~mm}$ (168 $\mathrm{mm}$ with the rostrum), in which the oostegites were only $20 \mathrm{~mm}$ long and $5 \mathrm{~mm}$ wide, i.e., not yet fully formed. Thus there seems to be a range for the size at which sexual maturity occurs in $G$. ingens with some individuals maturing at a smaller size than others.

\section{Gnathophausia gigas Willemoes-Suhm, 1875}

Fig. 5

\section{Gnathophausia drepanephora Holt and Tattersall, 1905}

A total of 66 specimens of Gnathophausia gigas were identified from the 1950-53 Scripps collections: 10 females, 9 males, and 47 juveniles, ranging in size from 21 to $142 \mathrm{~mm}$ body length. Table 3 presents information about the 5 specimens of $G$. gigas greater than $100 \mathrm{~mm}$ in body length.

The male of $164 \mathrm{~mm}$ total length (142 mm body length) from Station H51-355 is slightly larger than the previously reported largest specimen, a female of $160 \mathrm{~mm}$ total length (Tattersall, 1914). The next largest previously reported specimens were 2 females of $135 \mathrm{~mm}$ and 133 $\mathrm{mm}$ total length described by Nouvel (1943).

A single female measuring $105 \mathrm{~mm}$ body length from Station H51-366 possessed brood lamellae which were well developed into a completely formed brood pouch. The marsupium was empty, however, the embryos evidently having been recently discharged. The brood lamellae measured $27 \mathrm{~mm}$ in length and $8 \mathrm{~mm}$ at their greatest width. This mature female specimen was captured at a depth of 2972 $\mathrm{m}$ over a bottom depth of $3658 \mathrm{~m}$. It has been

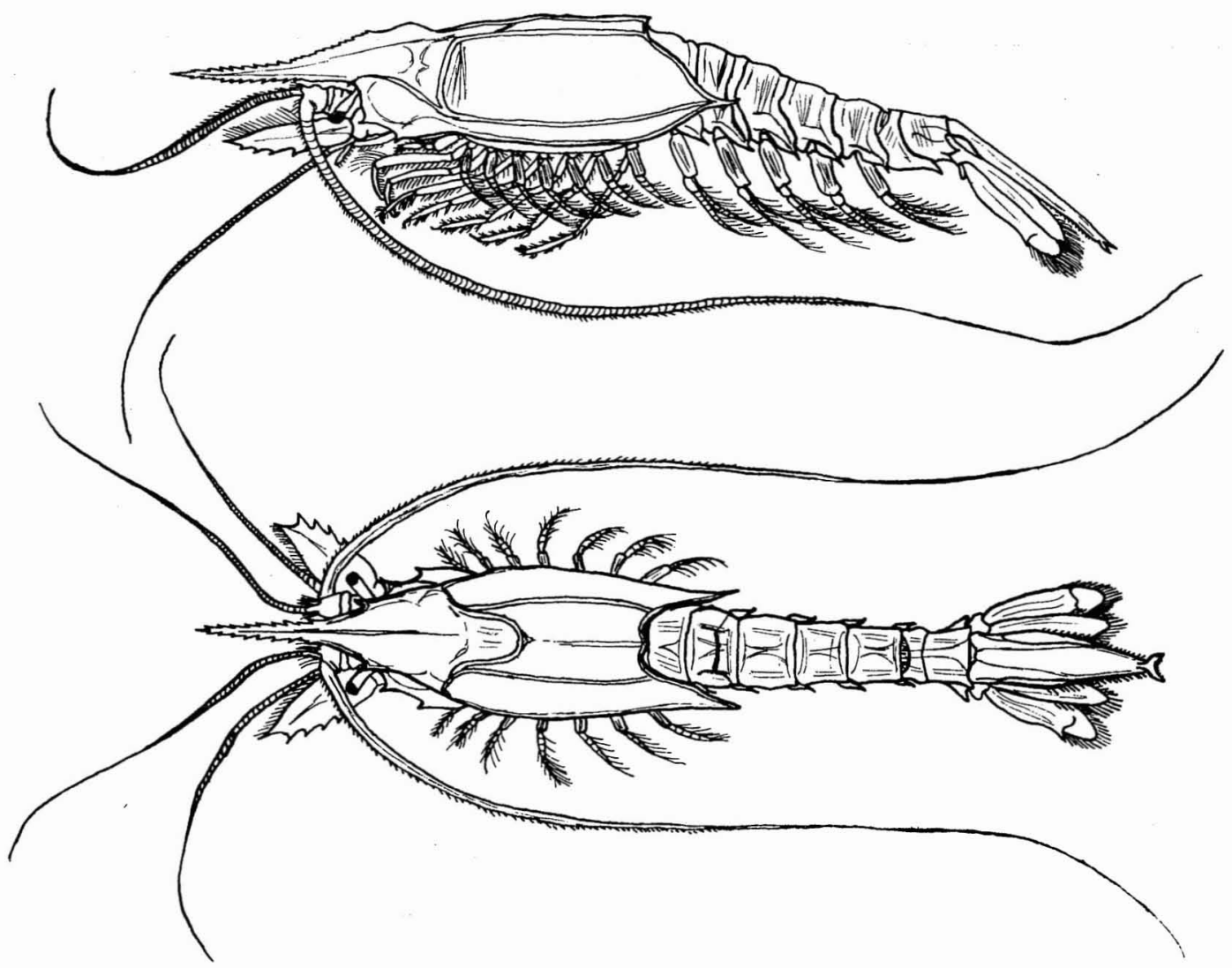

FIG. 5. Gnatbophausia gıgas, adult male of $142 \mathrm{~mm}$. (From Sars, 1885.) 
postulated by some that this species and possibly other species of Gnathophausia approach the bottom at sexual maturity, thus accounting for the difficulty in obtaining mature specimens with the traditional pelagic nets. It appears, however, that this mature specimen was not near the bottom, having been taken at least $600 \mathrm{~m}$ from the bottom when captured with the midwater trawl during the early hours of the morning (from 0300 to 0831 hours).

The minimum size for sexual maturity in this species is probably around $120 \mathrm{~mm}$ total length. Ortmann (1906) reports a female of $119 \mathrm{~mm}$ total length with fully developed oostegites forming a marsupial pouch. This is the smallest known sexually mature female of this species. On the other hand, the large female of $145 \mathrm{~mm}$ total length from the Scripps collections did not possess a fully developed marsupium. Apparently there is a range of size at which sexual maturity occurs, and it is a wide range in this species.

Gnathophausia gracilit Willemoes-Suhm, 1875 Fig. 6

\section{Gnathophausia brevispinis Wood-Mason, 1891.-Faxon, 1895 \\ " dentata Faxon, 1893 \\ " bidentata Illig, 1906}

A total of 128 specimens of Gnathophausia gracilis were identified from the Scripps 1950 53 collections: 64 females, 27 males, and 37 juveniles, ranging in size from $22 \mathrm{~mm}$ to 115 $\mathrm{mm}$ body length. Table 4 lists the individuals greater than $100 \mathrm{~mm}$ in body length. All 6 of these specimens are larger than the largest ones reported in previous literature. The nearly 250 specimens of $G$. gracilis gathered on the Dana Expedition and reported by Fage (1941) range in size from $20 \mathrm{~mm}$ to $100 \mathrm{~mm}$. The 3 largest Dana specimens (2 males and 1 female, each measuring $100 \mathrm{~mm}$ in body length) all came from the western Atlantic Ocean in the vicinity of the Caribbean Sea.

The single specimen from the Challenger Expedition described by Sars (1885) measured 41 $\mathrm{mm}$ total length (including rostrum). The 2 specimens from the Gulf of Bengal studied by Wood-Mason (1891) were immature and measured $83 \mathrm{~mm}$ and $92 \mathrm{~mm}$ total length. The John Murray Expedition collected 8 specimens from 22 to $78 \mathrm{~mm}$ in length. The Discovery Reports (Tattersall, 1955) list 3 specimens from 24 to $58 \mathrm{~mm}$ in size.

Fage (1941) states that the size at which $G$. gracilis reaches sexual maturity is greater in the Atlantic and Indian Oceans than in the Pacific; in the latter, especially the eastern $\mathrm{Pa}$ cific, there exists a relatively dwarf form of $G$. gracilis. He cites a small female of $52 \mathrm{~mm}$ taken in the Gulf of Panama on the Dana Expedition with a completely developed marsupium containing embryos. Fage indicates that there is no evidence that the adults of G. gracilis abandon their pelagic life in order to approach the bottom at the time of sexual maturity, and he shows that completely adult females were numerous at all levels in the pelagic fishings of the Dana. The smallest female adult

TABLE 3

Gnatbopausia gigas

Size AND LOCATION OF LARgEST SPECIMENS CAPtURED

\begin{tabular}{|c|c|c|c|c|c|}
\hline \multicolumn{2}{|c|}{ LENGTH $(\mathrm{mm})$} & \multirow[b]{2}{*}{ SEX } & \multirow[b]{2}{*}{ STATION* } & \multirow{2}{*}{$\begin{array}{l}\text { DEPTH OF } \\
\text { CAPTURE } \\
\text { (meters) }\end{array}$} & \multirow[b]{2}{*}{$\begin{array}{l}\text { APPROXIMATE } \\
\text { LOCATION* }\end{array}$} \\
\hline $\begin{array}{l}\text { Without } \\
\text { Rostrum }\end{array}$ & $\begin{array}{l}\text { Rostrum } \\
\text { Included }\end{array}$ & & & & \\
\hline $\begin{array}{l}142 \\
126 \\
110 \\
105 \\
102\end{array}$ & $\begin{array}{c}164 \\
145 \\
? \\
127 \\
125\end{array}$ & $\begin{array}{l}\text { M } \\
F \\
F \\
F \\
M\end{array}$ & $\begin{array}{l}\text { H51-355 } \\
\text { H51-161 } \\
\text { H51-90 } \\
\text { H51-366 } \\
\text { H51-371 }\end{array}$ & $\begin{array}{c}3400 \\
2085 \\
2213 \\
2972 \\
4023-4389\end{array}$ & $\begin{array}{l}\text { off Northern Calif. } \\
\text { off Baja California, Mex. } \\
\text { off Baja California, Mex. } \\
\text { off Alaska } \\
\text { off British Columbia }\end{array}$ \\
\hline
\end{tabular}

* See Table 1 for exact locations. 


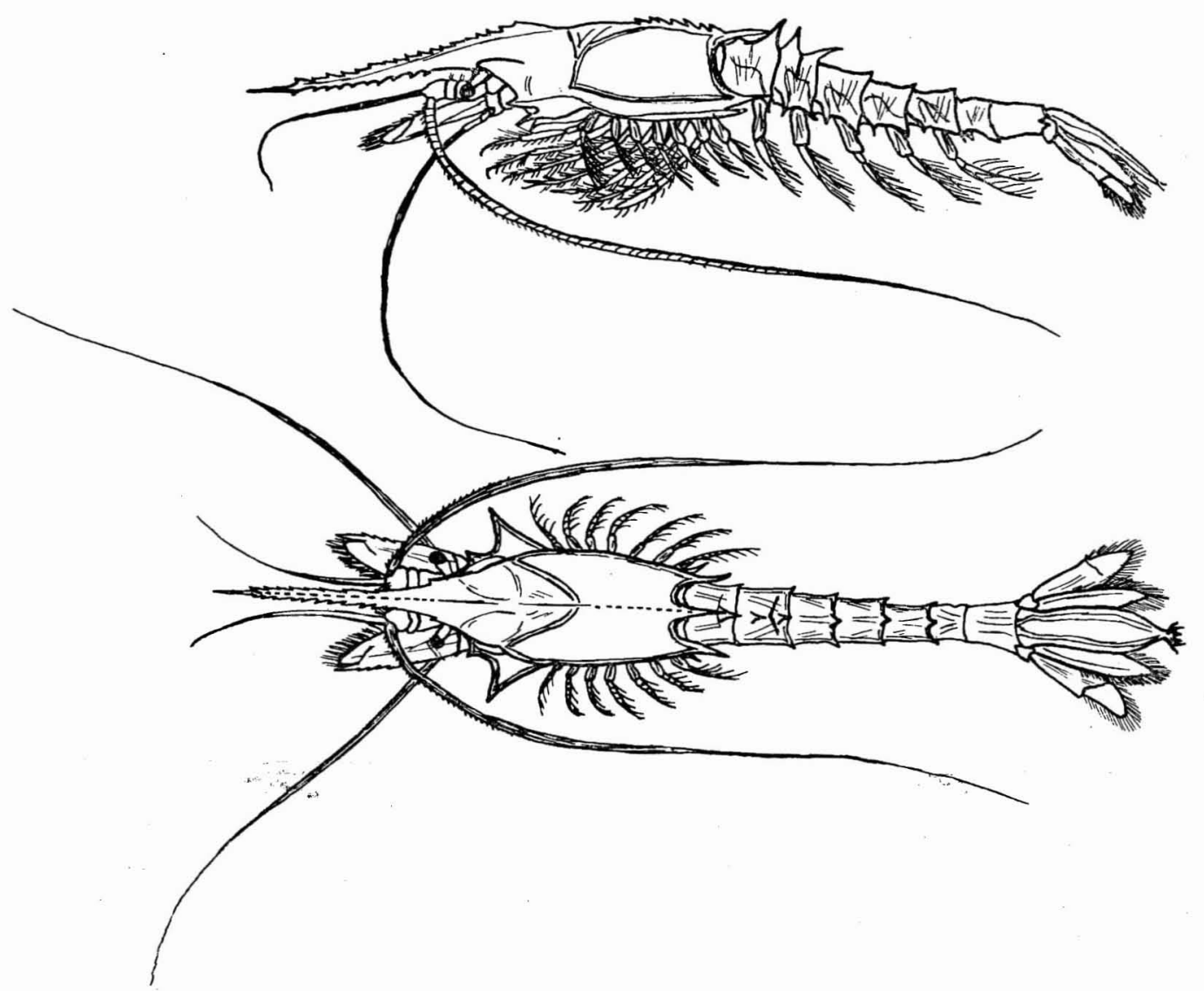

FIG. 6. Gnatbophausia gracilis, young male specimen of $41 \mathrm{~mm}$. (From Sars, 1885.)

with a completely formed brood pouch taken by the Dana also comes from the Gulf of Panama and measures $49 \mathrm{~mm}$ body length. Fage also points out that females of this size from the Caribbean Sea have only rudimentary oostegites and reach their sexual maturity at a larger size. The large female specimen taken from the Gulf of Bengal (Wood-Mason, 1891), measuring $92 \mathrm{~mm}$ total length, had incompletely developed brood lamellae which measured only 3 $\mathrm{mm}$ in length.

None of the 5 large females of greater than $100 \mathrm{~mm}$ body length from the Scripps collections possessed a completely formed brood pouch.

Gnathophausia zoea Willemoes-Suhm, 1875

Gnathophausia Willemoesi G. O. Sars 1885

" Sarsi Wood-Mason, 1891

" cristata Illig 1906
Only 2 specimens of Gnathophausia zoea (1 male and 1 female) were found in the Scripps 1950-53 collections. Both were taken at Station H52-404, located just south of the equator at $1^{\circ} 43^{\prime} \mathrm{S}, 89^{\circ} 52^{\prime} \mathrm{W}$ to $1^{\circ} 49^{\prime} \mathrm{S}, 90^{\circ} 00^{\prime} \mathrm{W}$. The depth of the haul was $1016 \mathrm{~m}$, over a bottom depth of 2560 to $2972 \mathrm{~m}$. In addition 4 other specimens of Gnathopbausia (all G. gracilis) were taken at this station, which was occupied during the time interval from 1944 to 0145 hours on August 8-9, 1952. The female G. zoea measured $48 \mathrm{~mm}$ body length (approximately $70 \mathrm{~mm}$ including the rostrum. The male measured $41 \mathrm{~mm}$ body length $(67 \mathrm{~mm}$ with the rostrum). This species is rarely taken off the west coast of North America.

Gnathophausia zoea has a wide horizontal distribution, occurring from the Arctic Circle to the Equator. It is especially widespread in 
the Atlantic Ocean and in the area of Indonesia in the South Pacific. Fage (1941) has contrasted its wide distribution in the Atlantic with its localization in the tropical zone in the Pacific.

Fage also points out that this species is less strictly bound to the great depths, occurring in a wide range of depths (from $200 \mathrm{~m}$ to $3000 \mathrm{~m}$ in the captures of the Dana Expedition). The 2 specimens from the Scripps collections came from approximately $1000 \mathrm{~m}$.

\section{HORIZONTAL DISTRIBUTION}

The Scripps 1950-53 collections studied hete were obtained from the eastern Pacific Ocean within an area extending to $160^{\circ} \mathrm{W}$ and between $60^{\circ} \mathrm{N}$ and $10^{\circ} \mathrm{S}$. Figure 7 shows the locations of captures of the three species of Gnathophausia predominant in the collections.

The more northerly species in the eastern Pacific is G. gigas, occurring mainly north of $30^{\circ} \mathrm{N}$. South of $40^{\circ} \mathrm{N} \mathrm{G}$. ingens takes over, ranging south to approximately $20^{\circ} \mathrm{N}$. Below $20^{\circ} \mathrm{N}$ there is only one station (Station $\mathrm{H} 52-$ 309 ) where $G$. ingens was identified from the Scripps collections, with the exception of the "giant" specimen of $G$. ingens described by Clark (1961), which was captured in 1955 between $7^{\circ} 50^{\prime} \mathrm{N}, 120^{\circ} 13^{\prime} \mathrm{W}$ and $8^{\circ} 12^{\prime} \mathrm{N}, 119^{\circ}$ $54^{\prime} \mathrm{W}$.

$G$. gracilis overlaps the distribution of $G$. ingens between $20^{\circ}-40^{\circ} \mathrm{N}$ and is the predominantly tropical form occurring in equatorial samples where neither of the other two species was found.

\section{Gnathophausia ingens}

The worldwide occurrence of $G$. ingens falls generally between $40^{\circ} \mathrm{N}$ and $40^{\circ} \mathrm{S}$. Within these limits we find some interesting variations in distribution in different portions of the world's oceans.

Figure 8 shows that $G$. ingens, although scarce in equatorial waters of the eastern $\mathrm{Pa}$ cific Ocean, is abundant in equatorial waters in other oceans. Fage (1941) comments on the rarity of this species east of the Samoan Islands in the eastern Pacific Ocean, as indicated by the captures of the Dana and previous expeditions. He speculates on the low oxygen tension in this area in the deep-water habitat of the species as being responsible for this lack of specimens. On the contrary, I have found that, off the coasts of California and Baja California, between $20^{\circ}-40^{\circ} \mathrm{N}, G$. ingens is the most abundant species of Gnatbopbausia in the Scripps collections taken from this portion of the eastern Pacific. It is more than twice as abundant in our captures from this region as is G. gracilis, and 18 times as numerous as $G$. gigas. G. ingens is, however, notably absent from our stations occupied in the equatorial zone where $G$. gracilis is the dominant species (Fig. 7). Whether $G$. ingens again becomes more abundant between $15^{\circ}$ and $40^{\circ} \mathrm{S}$ in the eastern Pacific is only speculation until samples can be studied from collections made in these areas. The samples studied here did not extend beyond $8^{\circ} \mathrm{S}$ (Station H52-363).

Possibly temperature is a factor in this dis-

TABLE 4

Gnathophausia gracilis

Size AND LOCATION OF LARgeST SPECIMENS CAPTURED

\begin{tabular}{|c|c|c|c|c|c|}
\hline \multicolumn{2}{|c|}{ SIZE $(\mathrm{mm})$} & \multirow[b]{2}{*}{ SEX } & \multirow[b]{2}{*}{ STATION* } & \multirow{2}{*}{$\begin{array}{c}\text { DEPTH OF } \\
\text { HAUL } \\
\text { (meters) }\end{array}$} & \multirow[b]{2}{*}{$\begin{array}{l}\text { APPROXIMATE } \\
\text { LOCATION* }\end{array}$} \\
\hline $\begin{array}{l}\text { Without } \\
\text { Rostrum }\end{array}$ & $\begin{array}{l}\text { Rostrum } \\
\text { Included }\end{array}$ & & & & \\
\hline 115 & 136 & $\mathrm{~F}$ & H51-84 & 914 & off Baja California, Mex. \\
\hline 113 & 138 & $\mathrm{~F}$ & $\mathrm{H} 51-77$ & 1810 & off Baja California, Mex. \\
\hline 113 & 134 & M & $\mathrm{H} 51-90$ & 2213 & off Baja California, Mex. \\
\hline 106 & 120 & $\mathrm{~F}$ & H51-77 & 1810 & off Baja California, Mex. \\
\hline 105 & $?$ & $\mathrm{~F}$ & H51-91 & 2012 & off Baja California, Mex. \\
\hline 103 & 122 & $\mathrm{~F}$ & H51-90 & 2213 & off Baja California, Mex. \\
\hline
\end{tabular}

See Table 1 for exact lozations. 


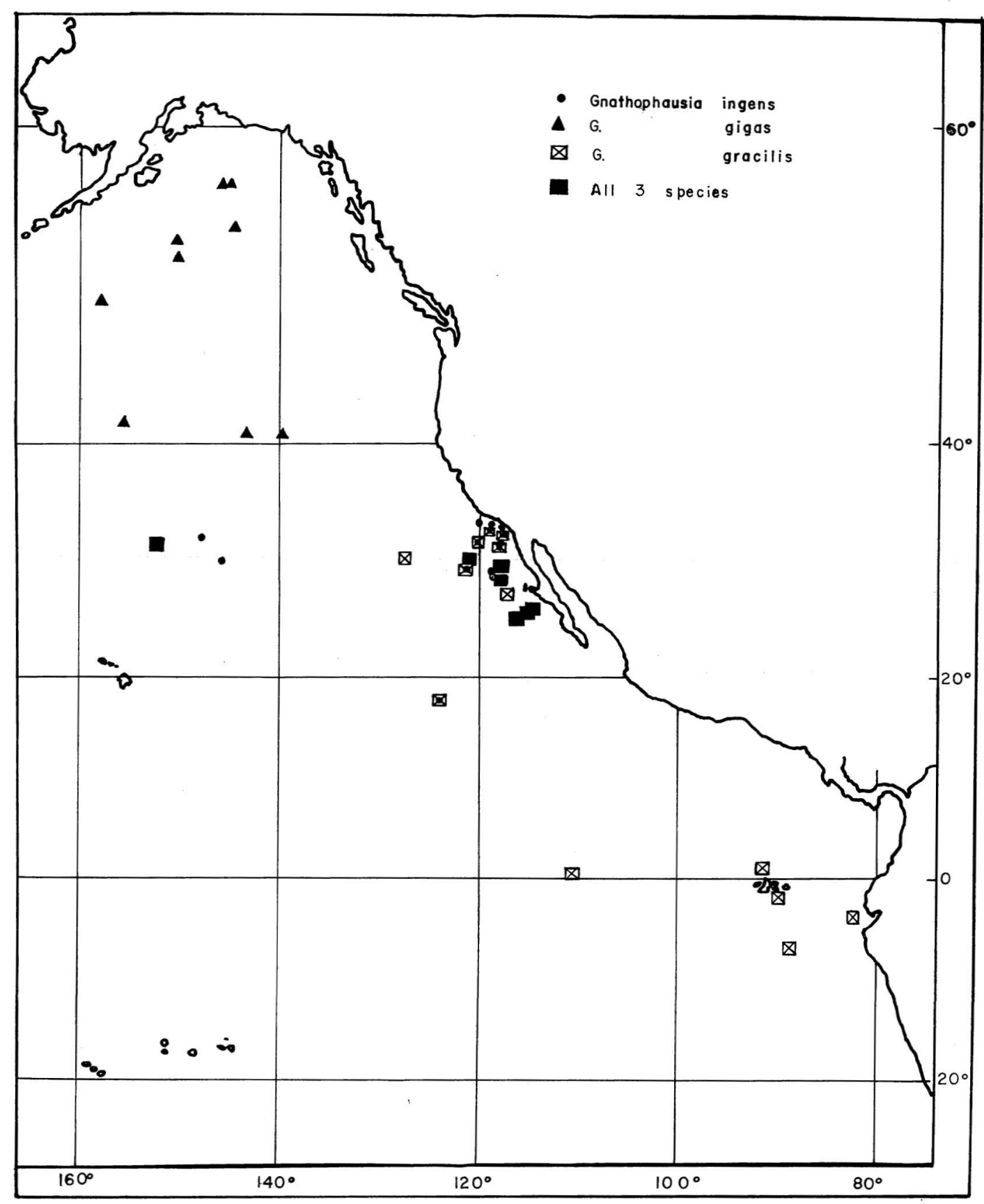

FIG. 7. Locations of captures of the three predominant species of Gnathophausia from the Scripps 195053 collections in the eastern Pacific Ocean. 


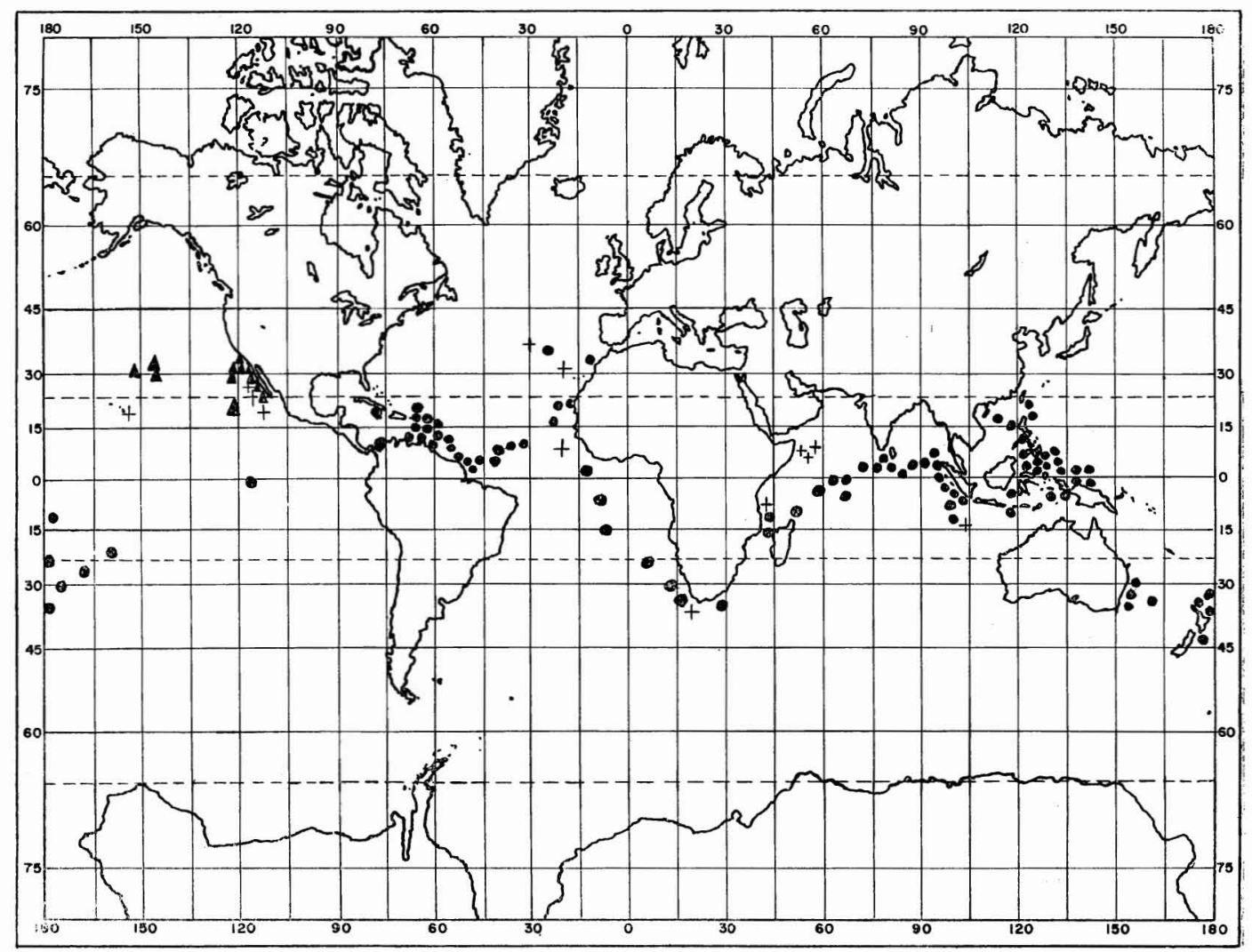

FIG. 8. Geographical Distribution of Gnatbopbausia ingens. Solid circle, captures of the Dana Expedition; plus sign, other previous captures; solid triangle, captures from the 1950-53 Scripps collections.

tribution between $15^{\circ} \mathrm{N}$ and $40^{\circ} \mathrm{N}$ in the eastern Pacific, but Figure 8 shows that the distribution of G.:ingens in the other oceans (especially in the Atlantic) and in other portions of the Pacific is not restricted to these latitudes. In the western Pacific and in the Indian Ocean this species is frequently found in the equatorial zones.

Figure 8 further shows that $G$. ingens occurs at mid-latitudes (between $20^{\circ}-40^{\circ} \mathrm{N}$ ) and is rare in the lower latitudes in the eastern portions of both the Atlantic and Pacific oceans. And, conversely, the species is more abundant in the lower latitudes and rare in mid- and higher latitudes in the western portions of both oceans. Fage (1941) correlates this strange distribution in the Atlantic with temperature isotherms at $600 \mathrm{~m}$. He has shown that the distribution of $G$. ingens falls within the zone of temperatures of less than $10^{\circ} \mathrm{C}$, and is excluded from areas of temperatures of greater than $10^{\circ} \mathrm{C}$.

\section{Gnathophausia gigas}

The wide latitudinal range of $G$. gigas is shown in Figure 9. This species is found from near the Equator to nearly $60^{\circ} \mathrm{N}$ in both the Atlantic and Pacific oceans. In the Southern Hemisphere $G$. gigas has been found as far south as $69^{\circ} \mathrm{S}$ in the Indian Ocean (Tattersall, $1955)$. In the Scripps $1950-53$ collections $G$. gigas was the only species of this genus which was taken north of $35^{\circ} \mathrm{N}$ in the eastern Pacific, having been found as far north as nearly $60^{\circ} \mathrm{N}$. Fage (1941) suggests that this animal prefers. the colder waters, and there is evidence that $G$. gigas lives deeper in the oceans where the 
superficial waters are warmer and lives in shallower water when these waters are colder, apparently seeking out temperatures in the $4^{\circ} \mathrm{C}$ isotherm region.

\section{Gnatbophausia gracilis}

This species, by contrast, is confined to a small latitudinal range between $35^{\circ} \mathrm{N}$ and $20^{\circ} \mathrm{S}$ (Fig. 10). Previously only four captures had been made outside the tropical zone (i.e., $23^{\circ} \mathrm{N}$ to $23^{\circ} \mathrm{S}$ ), these being taken from the Atlantic Ocean. None had been taken north of the Tropic of Cancer in the Pacific. However, of the 128 individuals of $G$. gracilis in the Scripps collections, a total of 99 specimens were found from stations north of the Tropic of Cancer. A great majority of the larger individuals (greater than $80 \mathrm{~mm}$ body length) came from north of the Tropic of Cancer, and all of the largest in- dividuals of greater than $100 \mathrm{~mm}$ body length came from north of $23^{\circ} \mathrm{N}$, the maximum latitude of occurrence being $33^{\circ} \mathrm{N}$. However, compared with the other species of Gnathophausia, $G$. gracilis was the most conspicuous species in the Scripps hauls from the tropical regions of the eastern Pacific, with no G. gigas and only a few $G$. ingens occurring in collections taken south of the Tropic of Cancer.

Fage (1941) reports that the $G$. gracilis found in the Pacific (especially in the eastern Pacific where, in the Gulf of Panama, the adults captured by the Dana did not exceed 65 $\mathrm{mm}$ length) are of smaller size than those of the Atlantic. His largest specimens (2 males and 1 female, each $100 \mathrm{~mm}$ in length) came from the Atlantic in the vicinity of the Caribbean Sea, and he believes that sexual maturity is more precocious in the specimens from the Pacific, particularly in the eastern Pacific, where

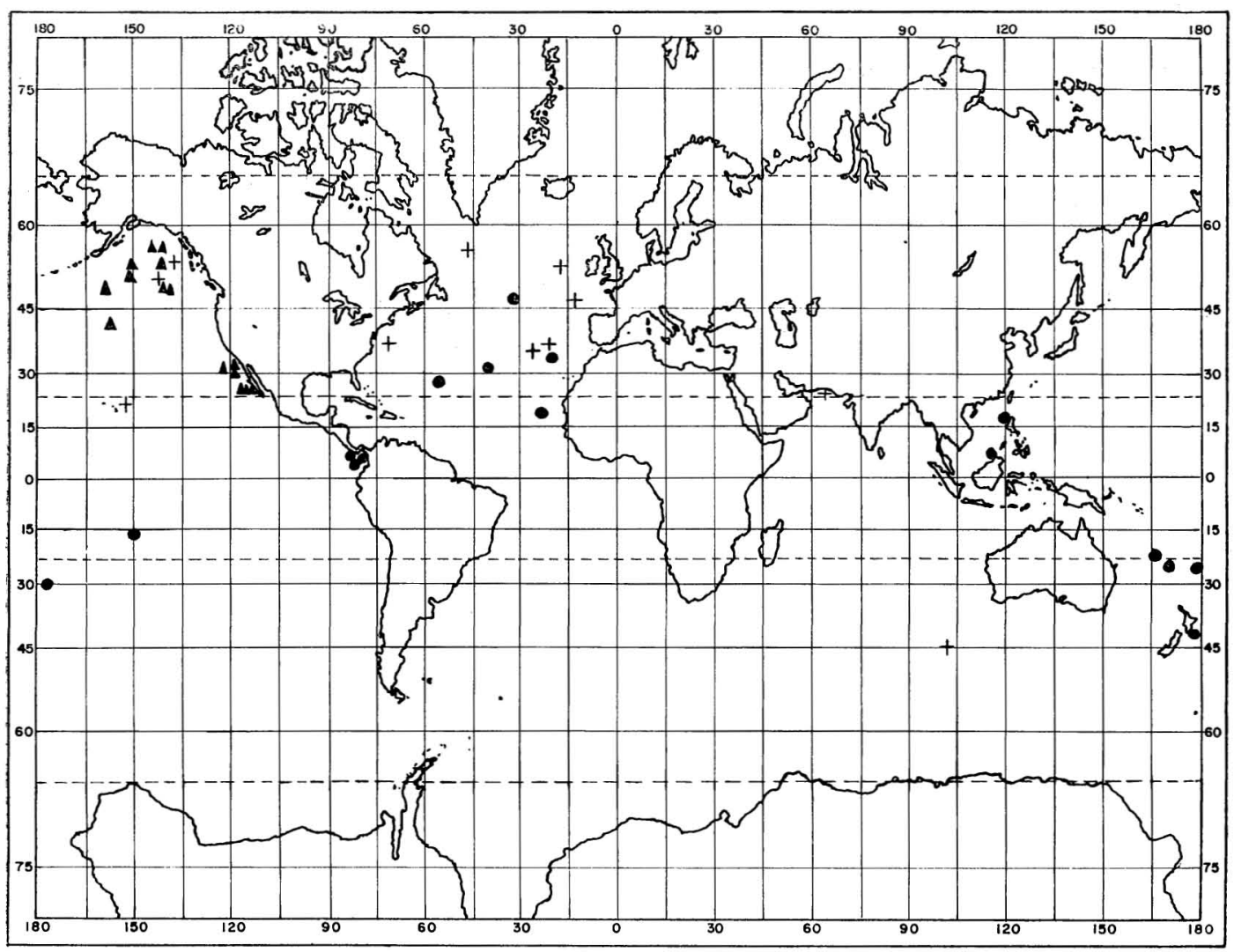

FIG. 9. Geographical Distribution of Gnatbopbausia gigas. Solid circle, captures of the Dana Expedition; plus sign, other previous captures; solid triangle, captures from the 1950-53 Scripps collections. 


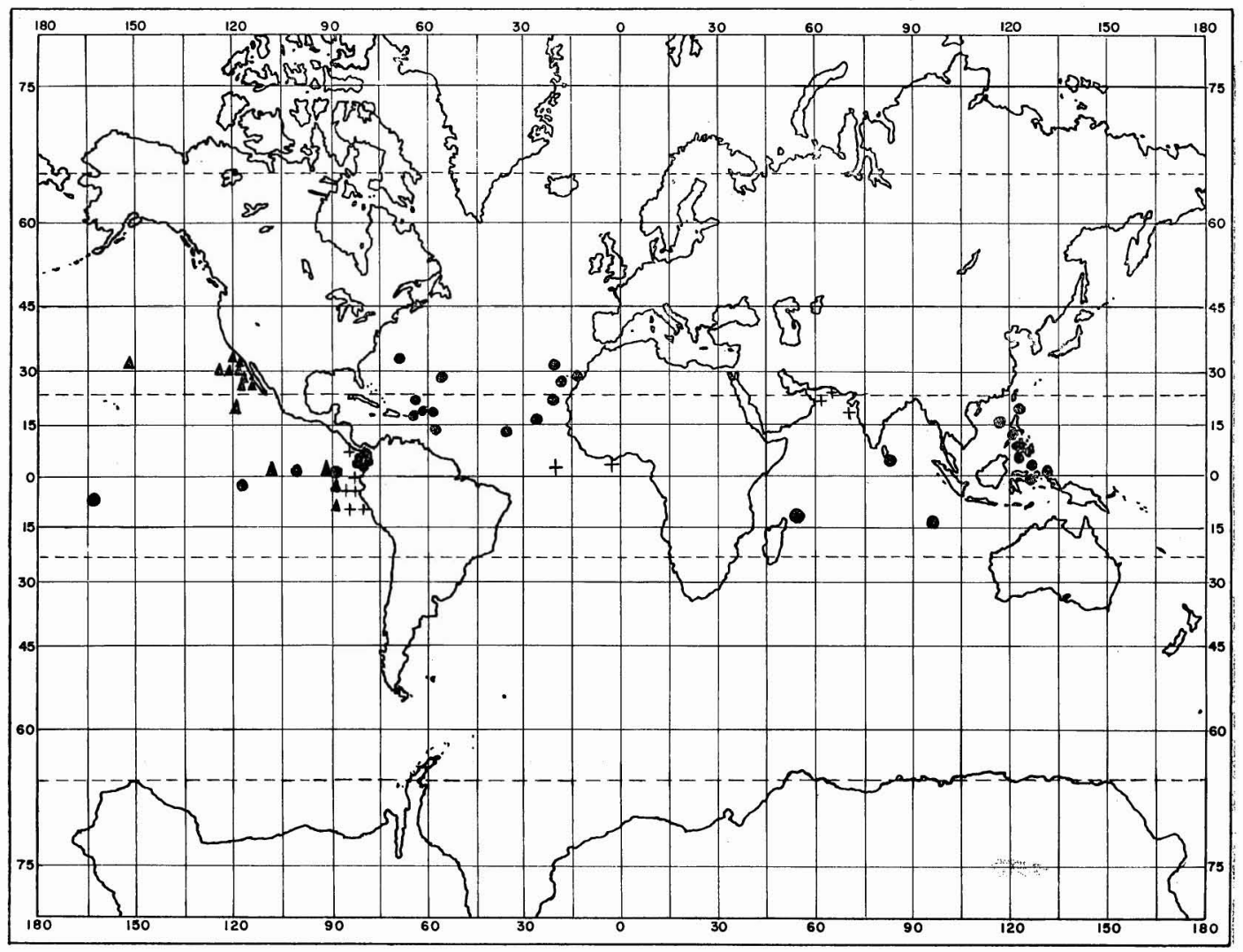

FIG. 10. Geographical Distribution of Gnathopbausia gracilis. Solid circle, captures of the Dana Expedition; plus sign, other previous captures; solid triangle, captures from the 1950-53 Scripps collections.

TABLE 5

DISTRIBUTIONOF Gnathophausia gracilis ACCORDING TO SIZE IN ATLANTIC AND PACIFIC OCEANS (FROM FAGE, 1941)

\begin{tabular}{c|c|c|c|c|c}
\hline \hline $\begin{array}{l}\text { NUMBER } \\
\text { OF INDI- } \\
\text { VIDUALS }\end{array}$ & LENGTH & \multicolumn{2}{|c|}{ ATLANTIC } & \multicolumn{2}{|c}{ PACIFIC } \\
\cline { 2 - 6 } & $(\mathrm{mm})$ & East & West & East & West \\
\hline 79 & $50-70$ & $5.0 \%$ & $2.5 \%$ & $58.2 \%$ & $34.2 \%$ \\
14 & $71-100$ & $7.1 \%$ & $57.1 \%$ & 0 & $35.7 \%$ \\
\hline
\end{tabular}

he found all the adults to be of relatively small size, as shown in Table 5.

Table 6 similarly illustrates the numbers and percentages of the various sized individuals in the Scripps collections taken from two portions of the eastern Pacific: (1) north of $23^{\circ} \mathrm{N}$ (where Fage lists no captures from the Dana), and
(2) south of $23^{\circ} \mathrm{N}$. Thus it can be seen that of the specimens coming from south of the Tropic of Cancer, the majority $(75.9 \%)$ are less than $80 \mathrm{~mm}$ in length (without the rostrum). This percentage actually refers to specimens under $60 \mathrm{~mm}$ in length, since no specimens between 61 and $80 \mathrm{~mm}$ were found in samples from this southern region in the Scripps collections. From the area north of the Tropic of Cancer the majority of the specimens taken $(59.6 \%)$ were of the larger size, i.e., greater than $80 \mathrm{~mm}$. Apparently the size difference noted by Fage would not apply to the entire eastern Pacific, but only to that portion within the tropical zone, and particularly in the area of the Gulf of Panama where, indeed, a dwarf form does seem to exist, which reaches sexual maturity at half the size of the normal adult $G$. gracilis. 
TABLE 6

DistrIBUTION OF Gnathophausia gracilis IN EASTERN PACIFIC ACCORDING TO SIZE

\begin{tabular}{|c|c|c|c|c|c|}
\hline \multicolumn{3}{|c|}{$\begin{array}{c}\text { EASTERN PACIFIC } \\
\text { NORTH OF TROPIC OF CANCER }\end{array}$} & \multicolumn{3}{|c|}{$\begin{array}{c}\text { EASTERN PACIFIC } \\
\text { SOUTH OF TROPIC OF CANCER }\end{array}$} \\
\hline $\begin{array}{l}\text { Number of } \\
\text { Individuals }\end{array}$ & $\begin{array}{l}\text { Length } \\
(\mathrm{mm})\end{array}$ & Percentage & $\begin{array}{l}\text { Number of } \\
\text { Individuals }\end{array}$ & $\begin{array}{l}\text { Length } \\
(\mathrm{mm})\end{array}$ & Percentage \\
\hline $\begin{array}{r}58 \\
41 \\
\text { Total } 99\end{array}$ & $\begin{array}{c}<80 \\
81-115\end{array}$ & $\begin{array}{l}59.6 \\
41.4\end{array}$ & $\begin{array}{r}22 \\
7 \\
\text { Total } 29\end{array}$ & $\begin{array}{c}<80 \\
81-115\end{array}$ & $\begin{array}{l}75.9 \\
24.1\end{array}$ \\
\hline
\end{tabular}

\section{VERTICAL DISTRIBUTION}

The Isaacs-Kidd Midwater Trawl is not equipped with a closing device, so that the exact depth of capture cannot be determined for specimens collected with this sampler. The maximum depth, however, is used as the assumed depth of capture, while recognizing that, although the majority of specimens were most likely captured at the maximum depth where the greatest length of trawling time is spent, there is still the possibility of catching stragglers between this depth and the surface as the net is raised. All depths of capture referred to in this paper have been calculated by measuring the amount of wire played out, then correcting for the wire angle to compute the actual collecting depth of the trawl.

Of the three predominant species of Gnatbophausia found in the Scripps collections from the eastern Pacific, G. gigas is the deepestoccurring (average depth of capture, $2100 \mathrm{~m}$ ). Another somewhat less deeply-occurring species is G. gracilis, with an average depth of capture in the Scripps collections of $1600 \mathrm{~m}$. $G$. ingens occurs predominantly in more shallow waters, where its average depth of capture was $1100 \mathrm{~m}$. A weighted average depth of capture for $G$. ingens was also calculated, taking into consideration the number of specimens captured at each depth. This weighted average depth of $850 \mathrm{~m}$ shows that the majority of specimens of $G$. ingens were found at an even more shallow average depth.

Time-depth graphs have been plotted for the three predominant species of Gnathophausia found in the 1950-53 Scripps collections (Figs. 11,12 , and 13), in order to detect any possible evidence of nocturnal vertical migrations.
In only one species, $G$. ingens, is there any evidence that the animals are found, in general, in more shallow water during night collections and in deeper water during daytime collections. The graph shows that during the day practically no specimens of $G$. ingens. were taken above $650-700 \mathrm{~m}$. On the other hand, the majority of captures at night recovered individuals from the zone between 274 and $650 \mathrm{~m}$. All captures at night from deeper than 650-700 $\mathrm{m}$ were from hauls which extended into the daylight period; thus there is the possibility that the specimens were picked up at these deeper levels during the daylight period of towing.

Similar time-depth graphs for G. gigas and $G$. gracilis do not seem to indicate any consistent depth differences between daylight and dark sampling. In order to study more precisely the possible existence of nocturnal vertical migration in Gnathophausia it would be necessary to employ the use of closing nets to determine more accurately the exact depths of capture. For even more accurate determinations a depth telerecording unit has been employed (Boden et al., 1955).

\section{Gnathophausia gigas}

Although G. gigas tends to occur at greater depths than the other two species, it was occasionally collected in more shallow water (less than $1000 \mathrm{~m}$ ) than that which Fage (1941) reports as the shallowest depth of occurrence of this species for the captures of the Dana (2000 $\mathrm{m}$ depth, $3000 \mathrm{~m}$ of wire out). The average depth of capture of $G$. gigas in the Scripps collections was $2100 \mathrm{~m}$, ranging from 600 to $4400 \mathrm{~m}$. Only 3 (19\%) of the 16 stations where $G$. gigas occurred were at less than 


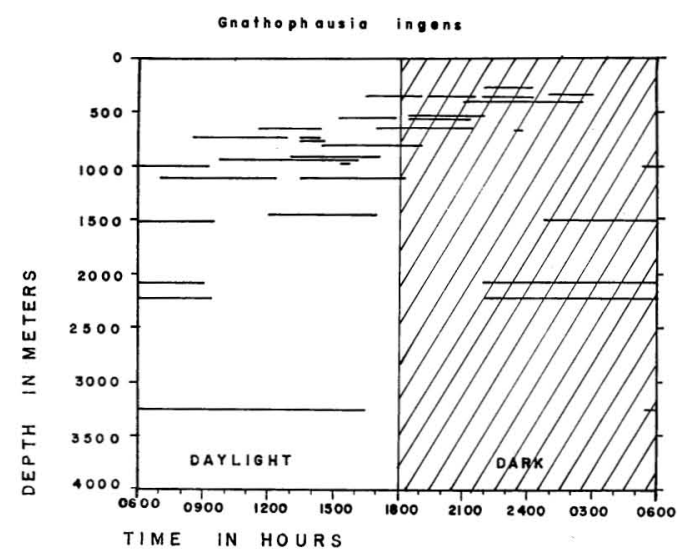

FIG. 11. Captures of Gnathophausia ingens plotted according to depth of haul and time of day.

$1000 \mathrm{~m}$. This involves 8 individuals (12\%) in the total of 66 individuals of this species examined. This compares with 20 of the 34 stations for $G$. ingens ( $59 \%$ ) which were at less than $1000 \mathrm{~m}$, and with 5 of the 22 stations $(23 \%)$ for $G$. gracilis. All specimens of $G$. gigas in the Scripps collections of greater than $100 \mathrm{~mm}$ body length came from depths of more than $2000 \mathrm{~m}$.

Closing nets used on the Discovery Expedition (Tattersall, 1955) found immature $G$. gigas at between 650-4000 $\mathrm{m}$ depth. Banner (1947) reports on 9 specimens of $G$. gigas from the eastern Pacific off Canada at between 400-1200 m depth, and 15 specimens off Alaska from depths of $300-900 \mathrm{~m}$. These specimens were all smaller than $60 \mathrm{~mm}$ body length.

\section{Gnathophausia gracilis}

$G$. gracilis has always been described as a species from very deep water (greater than $1500 \mathrm{~m}$ ). Previous reports show that all records of $G$. gracilis were from depths greater than $1500 \mathrm{~m}$, except for 2 young specimens described by Fage (1941) and Hansen (1927), which were from $800 \mathrm{~m}$. The Scripps collections yielded 30 individuals (collected at 5 separate stations) from depths of less than 1000 $\mathrm{m}$, some of them greater than $100 \mathrm{~mm}$ in size.

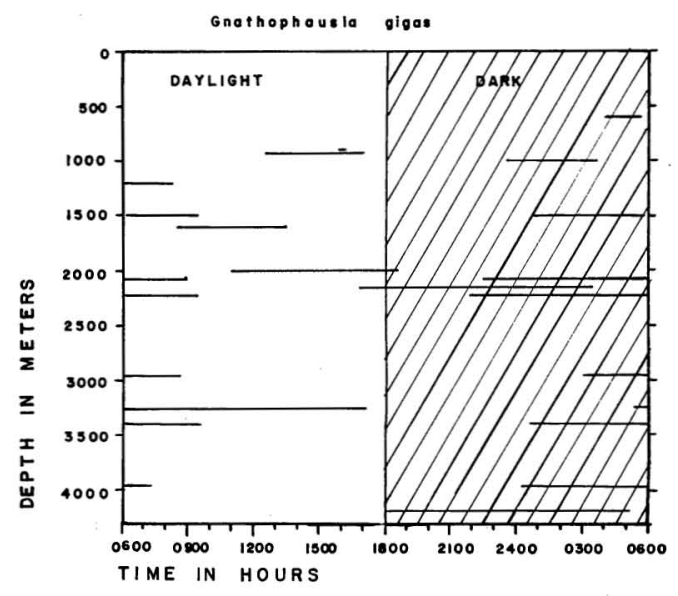

FIG. 12. Captures of Gnatbophausia gigas plotted according to depth of haul and time of day.

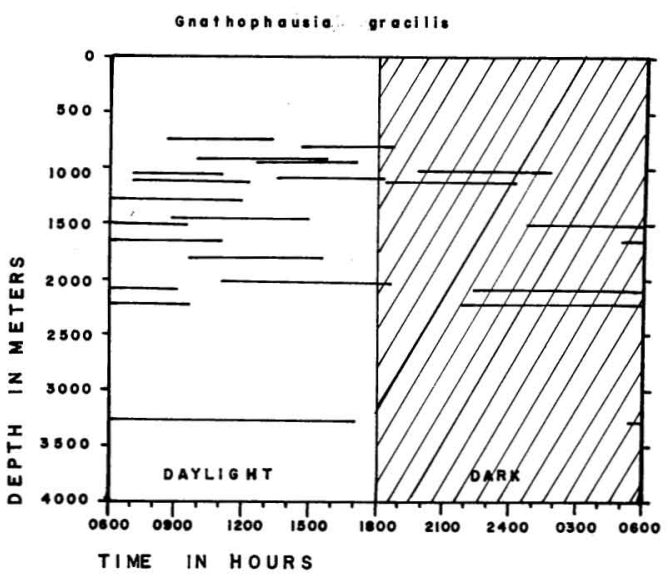

FIG. 13. Captures of Gnathophausia gracilis plotted according to depth of haul and time of day.

This amounts to $23 \%$ of the total of 128 individuals of this species examined in the Scripps collections. The 2 most shallow depths sampled yielding G. gracilis were $732 \mathrm{~m}$ (Sta. H50-277), with 1 small male, and $799 \mathrm{~m}$ (Sta. H51-45), with 6 juveniles and 3 males. The average depth of capture from the Scripps collections was 1600 $\mathrm{m}$, ranging from 732 to $3914 \mathrm{~m}$.

Fage (1941) suggested that $G$. gracilis maintains itself at a deeper level in the eastern por- 
tions of the Atlantic and Pacific oceans than in the western portions mainly in order to escape the zone of low oxygen content. Having studied the temperature, salinity, and oxygen content, he found that in the eastern portions the waters are colder, less saline, and poorer in oxygen content than at the same level in the western portions. Fage listed depths of between 1500 to $2000 \mathrm{~m}$ as the zone where G. gracilis normally lives. He pointed out that $G$. gracilis is a true bathypelagic species and not a form which lives on the bottom, as was previously believed. A study of Table 1, where the depth of haul and the bottom depth are given for the Scripps collections, also shows this to be true. In all stations where $G$. gracilis was found the depth of capture is from 400 to $2600 \mathrm{~m}$ from the bottom. The average difference between the depth of capture and the bottom depth for all positive stations of $G$. gracilis is $1512 \mathrm{~m}$, a considerable distance from the bottom.

\section{Gnatbophausia ingens}

$G$. ingens, in contrast to the other two species, occurs in greatest numbers above $1000 \mathrm{~m}$. The average depth of capture in the Scripps 1950-53 collections was $1100 \mathrm{~m}$, ranging from 274 to $3914 \mathrm{~m}$. The majority of specimens were found at an average depth of $850 \mathrm{~m}$ (weighted average). Closing nets on the Discovery Expedition (Tattersall, 1955) show that $G$. ingens was most common between 600 and $1500 \mathrm{~m}$, but was also found as deep as 2480 $2580 \mathrm{~m}$ and as shallow as $210-340 \mathrm{~m}$.

Previous studies have shown that the younger individuals of this species (less than $80 \mathrm{~mm}$ in length) are found at more shallow levels than are the larger, sexually mature adults. This is also generally true of the specimens from the Scripps collections. Fage (1941) has found that the peculiarities in vertical distribution, i.e., in certain areas of the Indian Ocean where young individuals were captured at considerably greater depths, can be explained by the vertical distribution of temperatures in those regions. He has found that the depth of occurrence of young individuals of less than $80 \mathrm{~mm}$ length corresponds to depths where the $5^{\circ}$ $8^{\circ} \mathrm{C}$ temperature range occurs. When this temperature occurs deeper, the young individuals occur deeper. He also states that in all the oceans no individual of a size greater than 80 $\mathrm{mm}$ has been taken with less than $1000 \mathrm{~m}$ of cable immersed, equivalent to an actual depth of $500-600 \mathrm{~m}$. This is generally true of the 1950-53 Scripps collections, with the exception of 2 specimens of 81 and $87 \mathrm{~mm}$ body length from Stations H51-75 and H51-76, both taken at a depth of $366 \mathrm{~m}$.

Although only 2 (or $8.7 \%$ ) of the 23 individuals of $G$. ingens of greater than $100 \mathrm{~mm}$ size were taken at less than $600 \mathrm{~m}$ (Sta. H5185 ), 17 (or $74.9 \%$ ) of the specimens were from depths less than $1000 \mathrm{~m}$ (Table 2).

Fage (1941) states that individuals of $G$. ingens exceeding $80 \mathrm{~mm}$ in length are very rare and account for $18 \%$ among the captures of the Dana in the Atlantic, for $13 \%$ in the Indian Ocean, and only $7 \%$ in the Pacific. From the Scripps collections in the eastern Pacific I have found that $26.5 \%$ of the individuals were greater than $80 \mathrm{~mm}$ in body length. This increase over Fage's figures serves to point out the improved sampling ability of the midwater trawl in deep waters over traditional pelagic nets. Larger and faster swimming specimens are less able to evade capture or to swim out of the nets, due to the greater speed and efficiency of the midwater trawl.

\section{PARASITES}

Fage (1936, 1940, and 1941) has described a curious protozoan parasite, Amallocystis fasciatus (an ellobiopsid flagellate), which occurs occasionally in specimens of Gnathophausia (Fig. 14). Of the 1,051 specimens examined from the Dana Expedition, 5 individuals were found which contained this parasite: 3 G. zoed and $2 G$. ingens.

Of the 400 individuals of the genus Gnatbophausia which I examined from the Scripps collections, I found only 3 parasitized specimens: $2 G$. ingens and $1 G$. gracilis. No previous record of parasitism by this flagellate has been reported in G. gracilis. This parasit- 


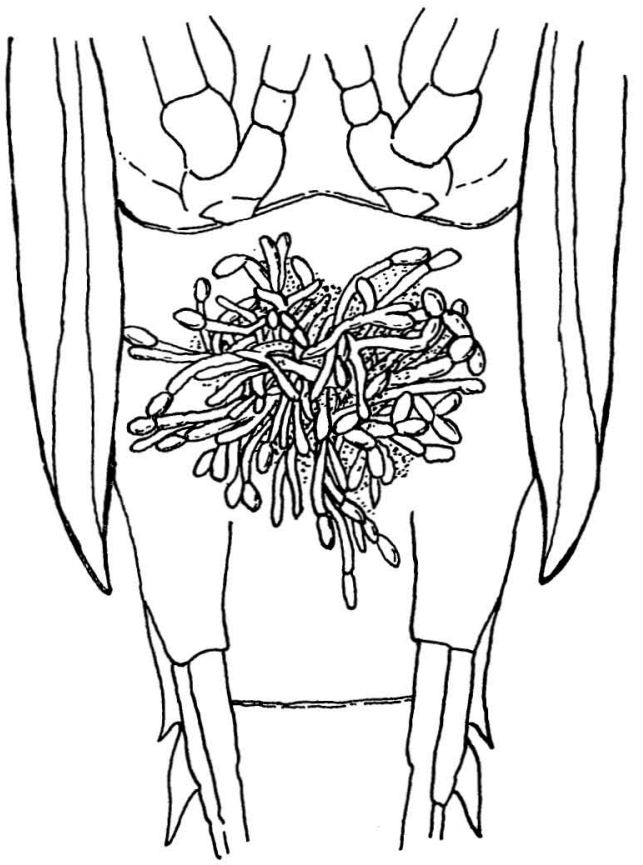

FIG. 14. First abdominal sternite of Gnathophausia zoea parasitized by Amallocystis fasciatus. (From Fage, 1941.)

ized G. gracilis is a female of $70 \mathrm{~mm}$ body length (87 $\mathrm{mm}$ including the rostrum) and was taken at Station H51-406 at a depth of 0-2926 m. Both parasitized G. ingens specimens are females, one of which came from Station H51-406 (from the same haul which captured the parasitized $G$. gracilis) at a depth of $0-2926 \mathrm{~m}$ and measured $86 \mathrm{~mm}$ body length (102 $\mathrm{mm}$ including the rostrum). The other parasitized $G$. ingens, a smaller female measuring $66 \mathrm{~mm}$ ( $82 \mathrm{~mm}$ including the rostrum), was taken at Station H52-15, the depth of capture being unknown over a bottom depth of $1207 \mathrm{~m}$. In each case the parasite was attached to the middle of the ventral aspect of the first abdominal segment. Indeed, Fage describes this exact location as being constant among the 5 parasitized individuals which he examined from the collections of the Dana.

Nouvel (1941) also reports on 4 similarly parasitized individuals from the following three species of Gnathophausia: (1) G. ingens-1 parasitized specimen (a male of $110 \mathrm{~mm}$ measured from the antennal scale to the end of the telson) from the eastern Atlantic off Mogador, Morocco, 0-4000 m; (2) G. gigas -1 parasitized female of $115 \mathrm{~mm}$ from the Atlantic Ocean south of Spain, 0-4740 m; (3) G. zoea-2 parasitized females of 45 and $39 \mathrm{~mm}$ from two locations in the eastern Atlantic off Portugal, one at $1241 \mathrm{~m}$, the other at $0-1500 \mathrm{~m}$.

Fage pointed out that the plate of fixation of this parasite is located just under the first abdominal nerve ganglion; and he observed a reaction of the host in the form of a great hypertrophy of this first abdominal ganglion as compared with the other abdominal and thoracic ganglia and with ganglia in normal, nonparasitized individuals.

Another influence of the parasite upon infected females is a retarded development of the secondary sexual characteristics, particularly the oostegites, which were considerably smaller and less well developed in the parasitized females than in non-infected females of the same size and presumably, of the same age. In addition, Nouvel describes an effect on the male $G$. ingens. In this male the sexual orifice is at the base of the last thoracic appendages. In addition this specimen has some very small outlines of oostegites at the bases of all the thoracic appendages except the last pair. This has been described as a "feminizing action" which the parasite exercises on the host.

In the 2 parasitized females of $G$. ingens from the Scripps collections, a retarded development in the oostegites was noted as compared with the normal, non-parasitized females. In both the $66 \mathrm{~mm}$ specimen and the $86 \mathrm{~mm}$ specimen the oostegites were extremely minute, less than $1 \mathrm{~mm}$ in length. A normal female of only $70 \mathrm{~mm}$ was found to have oostegites $2 \mathrm{~mm}$ in length, and a non-parasitized female of 80 $\mathrm{mm}$ possessed oostegites measuring $3 \mathrm{~mm}$.

However, in the case of the parasitized $G$. gracilis of $65 \mathrm{~mm}$ which I examined, the oostegites measured $4 \mathrm{~mm}$ in length and $1 \mathrm{~mm}$ in width. These measurements are similar to those for normal, non-parasitized females of this species of approximately the same length. Thus the parasite does not seem to have retarded the development of the oostegites in this parasitized $G$. gracilis, in contrast to its effects on the other species of Gnatbophausia. 


\section{SUMMARY}

1. A total of 400 specimens of Gnathophausia were studied from the Scripps Institution of Oceanography's 1950-53 collections made with the Isaacs-Kidd Midwater Trawl, in the eastern Pacific Ocean, and four species were identified: (a) G. ingens: 204 specimens ranging in size from 25 to $139 \mathrm{~mm}$ body length (not including the rostrum), taken from a depth range of 274-3914 m, with an average depth of capture of $1100 \mathrm{~m}$; (b) G. gigas: 66 specimens ranging in size from 21 to $142 \mathrm{~mm}$ body length, taken from a depth range of $603-4883 \mathrm{~m}$, with an average depth of capture of $2100 \mathrm{~m}$; (c) G. gracilis: 128 specimens ranging in size from 22 to $115 \mathrm{~mm}$ body length, taken from a depth range of 732-3914 $\mathrm{m}$, with an average depth of capture of $1600 \mathrm{~m}$; (d) G. zoea: 2 specimens, a female of $48 \mathrm{~mm}$ body length and a male of $41 \mathrm{~mm}$ body length, taken from a depth of 0-1016 m.

2. The geographical distribution of G. gigas, a colder water form, in the eastern Pacific is more northerly $\left(20^{\circ}-60^{\circ} \mathrm{N}\right)$ than is that of $G$. ingens and $G$. gracilis, which occur in warmer waters and exhibit a more tropical distribution, particularly G. gracilis.

3. Of the 128 specimens of $G$. gracilis collected 99 were found north of the Tropic of Cancer in the eastern Pacific Ocean, an area where they had rarely been found previously.

4. G. ingens was found consistently deeper in daylight hauls than in hauls taken at night, possible evidence for nocturnal vertical migration in this species. No evidence for this phenomenon is shown for G. gigas or G. gracilis.

5. Among the specimens of $G$. gracilis 6 were greater than $100 \mathrm{~mm}$ in body length, the largest measuring $115 \mathrm{~mm}$. All are larger than any $G$. gracilis individuals previously described.

6. A mature female specimen of $G$. gigas measuring $105 \mathrm{~mm}$ in body length and having a well developed marsupium is described.

7. A parasitic ellobiopsid flagellate, Amallocystis fasciatus, is reported from 2 specimens of $G$. ingens and 1 specimen of $G$. gracilis taken from the eastern Pacific Ocean.

\section{ACKNOWLEDGMENTS}

This study was undertaken at the Scripps Institution of Oceanography in 1955, while I was studying under a National Science Foundation Pre-Doctoral Fellowship under the guidance of Dr. Martin W. Johnson.

\section{REFERENCES}

BANNer, Albert H. 1947. A taxonomic study of the Mysidacea and Euphausiacea (Crustacea) of the northeastern Pacific, Part I. Trans. Roy. Can. Inst. 26:345-414.

_ 1954. Some "schizopod" crustaceans from the deeper water off California. Allan Hancock Found. Publ., Occas. Paper No. 13.

BoAs, J. E. V. 1883. Studien über die Verwandtschaftsbeziehungen der Malakostraken. Morph. Jahrb. 8:485-579.

BODEN, BRIAN P., E. M. KAMPA, J. M. SNODGRASs, and R. F. DeVEReUX. 1955. A depth telerecording unit for marine biology. J. Mar. Res. 14(2) : 205-209.

Calman, W. T. 1904. On the classification of the Crustacea Malacostraca. Ann. Mag. Nat. Hist. 13 (7) : 144-158.

Clark, William D. 1961. A giant specimen of Gnathophausia ingens (Dohrn 1870) (Mysidacea) and remarks on the asymmetry of the paragnaths in the suborder Lophogastrida. Crustaceana 2(4):313-324.

Dohrn, ANTON. 1870. Untersuchungen über Bau und Entwicklung der Arthropoden, 10. Beiträge zur Kenntniss der Malacostraken und ihrere Larven. Zeit. Wiss. Zool. 20:607626.

FAGE, Louis. 1936. Sur un Ellobiopside nouveau, Amallocystis fasciatus, n.g., n.sp., parasite des Mysidaces bathypélagiques. Arch. Zool. Exptl. Gen. 78:287-291.

1940. Sur le déterminisme des caractères sexuels secondaires des Lophogastrides. C. R. Acad. Sci. 211:335-337.

1941. Mysidacea, Lophogastrida, I. Dana Report 19:1-52. 
FaXoN, W. 1893. Bull. Mus. Compar. Zool. 24: 217.

1895. Stalk-eyed Crustacea of the Albatross Expedition. Mem. Mus. Harvard 18:1292.

Hansen, Hans Jacob. 1893. Zur Morphologie der Gleidmassen und Mundteile bei Crustacean und Insecten. Zool. Anz. 16:193-212. Translation in Ann. Mag. Nat. Hist. 12 (6): 417-434.

1927. Sergistides et schizopodes. Exped. sci. du "Travailleur" et du "Talisman," 18801883. pp. 1-27. Masson, Paris.

Holt, E. E. L., and W. M. Tattersall. 1905. Report of the Schizopoda collected by $\mathrm{Mr}$. George Murray during the cruise of the "Oceania" in 1898. Ann. Mag. Nat. Hist. 16(7):1-10.

ILLIG, G. 1906. Ein weiterer Bericht über die Schizopoden der Deutschen Tiefsee Expedition 1898-1899. Zool. Anz. 30 (7 and 10).

LAtreille, P. A. 1817. Les crustacés. In: Le règne animal distribué d'après son organisation Cuvier, 3:1-72. Paris.

Nouvel, Henri. 1941. Sur les ellobiopsides des mysidacés provenant des campagnes du Prince de Monaco. Bull. Inst. Oceanog., 809.

1943. Mysidacés provenant des campagnes du Prince Albert $1^{\text {er }}$ de Monaco. In: Jules Richard, Résultats des campagnes Monaco, 105:1-128.
Ortmann, Arnold E. 1906. Schizopod crustaceans in the U. S. National Museum. The families Lophogastridae and Eucopiidae. Proc. U. S. Nat. Mus. 31 (36) :23-52.

SARS, G. O. 1885. Challenger Reports, 13.

SIO REFERENCE 53-3. 1953. Isaacs-Kidd Midwater Trawl. Oceanographic Equipment Report No. 1, Univ. Calif., Scripps Inst. Oceanog.

Tattersall, Olive. 1955. Mysidacea. Discovery Reports 28:1-190. Cambridge Univ. Press.

TAtTersall, Walter M. 1914. The Schizopoda, Stomatopoda, and non-arctic Isopoda of the Scottish National Antarctic Expedition. Trans. Roy. Soc. Edinburgh 49(4): 865-894.

- 1951. A review of the Mysidacea of the U. S. National Museum. U. S. Nat. Mus. Bull. 201:25-32.

and Olive S. Tattersall. 1951. The British Mysidacea. Ray Society, London.

WILlemoes-SuHM, R. V. 1875. On some Atlantic Crustacea from the Challenger Expedition. Trans. Linn. Soc. London, Zool. 2(I): 23-58.

Wood-MASON, J., and A. AlCOCK. 1891. Natural history notes from $\mathrm{H}$. M. Marine Steamer "Investigator." Ann. Mag. Nat. Hist. 6(8): 269. 